( ) institute of development studies

IDS Working Paper

Volume 2020 Number 543

CSP Working Paper 018

Policy Pollination: A Brief History of Social Protection's Brief History in Africa

Stephen Devereux

December 2020 
The Institute of Development Studies (IDS) delivers world-class research, learning and teaching that transforms the knowledge, action and leadership needed for more equitable and sustainable development globally.

The Centre for Social Protection (CSP) supports a global network of partners working to mainstream social protection in development policy and encourage social protection systems and instruments that are comprehensive, long term, sustainable and pro-poor. We produce research on conceptual approaches; design issues, including delivery and targeting; and impacts of different social protection initiatives.

Email: socialprotection@ids.ac.uk

Web: www.ids.ac.uk/programme-and-centre/centre-for-social-protection/

CSP WP018

CSP Working Paper series editor: Stephen Devereux

institute of development studies

\section{Sip Centre for Social Protection}

Global Dynamics of Social Policy CRC 1342

(C) Institute of Development Studies 2020

IDS Working Paper Volume 2020 Number 543

CSP Working Paper 018

Policy Pollination: A Brief History of Social Protection's Brief History in Africa

Stephen Devereux

ORCID: 0000-0002-4885-0085

December 2020

First published by the Institute of Development Studies in December 2020

ISSN: 2040-0209 ISBN: 978-1-78118-734-0

DOI: $10.19088 / I D S .2020 .004$

A catalogue record for this publication is available from the British Library

This paper is written and published in collaboration with the SOCIUM Research Centre on Inequality and Social Policy, University of Bremen.

No potential conflict of interest was reported by the authors.

This is an Open Access paper distributed under the terms of the Creative Commons Attribution Non Commercial 4.0 International licence (CC BY-NC), which permits use, distribution and reproduction in any medium, provided the original authors and source are credited, any modifications or adaptations are indicated, and the work is not used for commercial purposes.

Available from:

Institute of Development Studies, Library Road

Brighton, BN1 9RE, United Kingdom

+44(0)1273915637

ids.ac.uk

IDS is a charitable company limited by guarantee and registered in England

Charity Registration Number 306371

Charitable Company Number 877338 
IDS Working Paper

Volume 2020 Number 543

CSP Working Paper 018

\section{Policy Pollination: A Brief History of Social Protection's Brief History in Africa}

Stephen Devereux December 2020 


\title{
Policy Pollination: A Brief History of Social Protection's Brief History in Africa
}

\author{
Stephen Devereux \\ December 2020
}

\section{Summary}

The relatively recent emergence and sustained rise of social protection as a policy agenda in Africa can be understood as either a nationally owned or 'donordriven' process. While elements of both can be seen in different countries at different times, this paper focuses on the pivotal role of transnational actors, specifically international development agencies, as 'policy pollinators' for social protection. These agencies deployed a range of tactics to induce African governments to implement cash transfer programmes and establish social protection systems, including: (1) building the empirical evidence base that cash transfers have positive impacts, for advocacy purposes; (2) financing social protection programmes until governments take over this responsibility; (3) strengthening state capacity to deliver social protection, through technical assistance and training workshops; (4) commissioning and co-authoring national social protection policies; (5) encouraging the domestication of international social protection law into national legislation. Despite these pressures and inducements, some governments have resisted or implemented social protection only partially and reluctantly, either because they are not convinced or because their political interests are not best served by allocating scarce resources to cash transfer programmes. This raises questions about the extent to which the agendas of development agencies are aligned or in conflict with national priorities, and whether social protection programmes and systems would flourish or wither if international support was withdrawn.

\section{Keywords}

Social protection, policy process, coercive diffusion, international development agencies, sub-Saharan Africa. 


\section{Author}

Stephen Devereux is a Researcher and Co-Director of the Centre for Social Protection at the Institute of Development Studies, UK. He holds the National Research Fund - Newton Fund Bilateral South Africa - UK Research Chair in Social Protection for Food Security at the University of the Western Cape in South Africa, where he is affiliated with the Institute for Social Development and the DSI-NRF Centre of Excellence in Food Security. He also holds a Mercator Fellowship at the SOCIUM Research Centre on Inequality and Social Policy, University of Bremen in Germany. 


\section{Executive Summary}

The emergence and rapid rise of social protection as a development policy agenda in Africa is well documented, but how this 'success story' happened is less well understood. This paper contributes to an emerging strand of literature that explores why social protection spread so rapidly throughout sub-Saharan Africa in the first two decades of this century. Four causal mechanisms for policy transfer between neighbouring or distant countries are discussed in the literature: learning, competition, emulation, and coercion. A fifth mechanism is identified in this paper, which is closely aligned to coercion. 'Policy pollination' involves international development agencies using their soft power of financial and technical assistance, to persuade aid-dependent governments to implement and scale up social protection, especially social cash transfer programmes, and to develop and institutionalise national social protection policies and systems.

Policy pollination has been deployed as a tactic by development agencies for decades, from structural adjustment in the 1980s to Poverty Reduction Strategy Papers in the early 2000 s to social protection since then. Three agencies are identified as the leading global 'pollinators' in the social protection policy transfer process - ILO, UNICEF, and the World Bank - and five mechanisms of policy pollination are then identified and discussed.

First, development agencies invested heavily in building the evidence base that social protection programmes - starting with donor-funded pilot projects contribute to positive outcomes such as food security and poverty reduction. This was done mainly for advocacy purposes: to demonstrate effectiveness of aid spending to their domestic constituencies, and to convince governments in Africa to take over the running and financing of national social protection programmes.

Second, development agencies invested directly in financing social protection programmes in Africa, especially cash transfer pilot projects in low-income countries where governments were reluctant to dedicate substantial public resources to national programmes because of concerns about (un)affordability. This financial support was intended to be transitional: as national incomes rise and governments become convinced by social protection's positive impacts they are expected to take over funding these programmes themselves - the 'funding seesaw'.

Third, development agencies have invested in capacity strengthening of African governments to design and implement programmes and build social protection systems. Mechanisms include training workshops, high-level dialogues, study tours, and embedding expatriate consultants in government ministries. The World Bank and ILO run their own training workshops, which 
allows these agencies to disseminate their preferred social protection approaches to participants, who include influential policymakers and practitioners from low- and middle-income countries.

Fourth, development agencies have initiated and supported processes of producing national social protection policies. In the year 2000 , no country in Africa had a social protection policy or strategy. By 2010, this had risen to only five, but 30 countries promulgated a policy or strategy in the next nine years, mostly following donor-driven processes. In some cases, the logos of development agencies appear on the cover of these policy documents, alongside the national coat of arms.

Fifth, development agencies such as ILO have promoted the domestication of international social protection law into national policies and laws, by advocating for rights-based approaches that are grounded in globally ratified documents such as the Universal Declaration of Human Rights (1948) and the Recommendation on Social Protection Floors (2012). Although this is 'soft law' at international level, once written into national legislation or a country's Constitution local civil society can hold their government accountable to deliver on the right to social protection.

Despite this array of 'policy pollination' strategies used by international development agencies to induce African countries to adopt and scale up social protection, some governments have consistently resisted this pressure. This paper identifies two possible reasons for this resistance. One is that the constituencies prioritised by African governments (such as farmers and middle class citizens) do not coincide with vulnerable groups identified by development agencies as priorities for social protection (such as poor children and older persons). The second possibility is that there is genuine disagreement between African governments and their development partners about whether social protection - and specifically targeted cash transfers - is the most effective set of instruments for achieving national policy goals such as food security and poverty reduction. 


\section{Contents}

Acknowledgements

1. Introduction

2. 'Policy pollination' as a development tactic

3. International development agencies as 'policy pollinators'

4. 'Policy pollination' mechanisms

4.1 Building the evidence base

4.2 Financing social protection programmes

4.3 Strengthening capacities to deliver social protection

4.4 Instigating national social protection policies or strategies

4.5 Domestication of international law

5. Understanding resistance: why some governments say 'no' 


\section{Boxes}

Box 4.1 Regional Hunger and Vulnerability Programme

\section{Figures}

Figure 2.1 New national social protection policies or strategies in Africa by year, 2000-2019 16

Figure 4.1 Share of donor and government funding of social assistance in sub-Saharan Africa 32

Figure 4.2 Cumulative National Social Protection Policies/Strategies in Africa, 2000-2019 38

Figure 4.3 Cover of World Bank report on a social protection policy for Togo 40

Figure 4.4 Covers of The Gambia and Liberia National Social Protection Policies 41

\section{Tables}

Table 4.1 National Social Protection Policies or Strategies in Africa by region, 2019

Table 4.2 Ratification by African countries of international social protection law 


\section{Acknowledgements}

This paper builds on presentations by the author at the universities of Bath, Bremen, Maastricht, Southern Denmark and the Institute of Development Studies, the Development Studies Association Annual Conference (UK, 2019) and the Social Policy in Africa conference (South Africa, 2019). The ideas in this paper have been informed by participants at these conferences and seminars. The author thanks two referees, Rachel Sabates-Wheeler and Carina Schmitt, for their insightful comments on earlier drafts. This work is supported by the National Research Foundation of South Africa (Grant Number: 98411) and the Newton Fund, administered by the British Council, as well as a Mercator Fellowship with the SOCIUM Research Centre on Inequality and Social Policy at the University of Bremen, Germany. 


\section{Introduction}

Social protection is an indisputable success story of development policy and practice, especially in sub-Saharan Africa. At the global level, social protection was not mentioned at all in the Millennium Development Goals (United Nations 2000), but just 15 years later it featured in three of the 17 Sustainable Development Goals (United Nations 2015), with targets that are being monitored under Agenda 2030. At the continental level, not a single country in Africa had a national social protection policy in the year 2000 , but almost two-thirds (35 out of 55 ) had produced a policy or strategy by 2019. Although the coverage of social protection programmes remains relatively limited, millions of Africans who had no access 20 years ago now receive regular social assistance, typically in the form of monthly cash transfers (UNDP 2019).

As social protection has established itself as an essential social policy sector, alongside and linked to education and health, so the literature surrounding it has evolved. Crudely, three phases can be identified. In the first decade of the century, much effort was invested in trying to establish whether social protection programmes are effective (do they work?), mainly through commissioned impact evaluations (this is discussed below as 'building the evidence base'). By 2010 , the balance of evidence was tilting heavily towards the positive: the case for social protection, even in the poorest countries, was effectively proven. Although impact evaluations continue, they now focus on testing design innovations and assessing progress towards programme objectives in particular contexts. Accordingly, the emphasis shifted towards institutionalising social protection ensuring that governments have the necessary capacity to run programmes efficiently, that social protection was scaled-up from donor-driven projects to nationally owned programmes, and putting in place systems such as beneficiary databases and electronic payment mechanisms, all underpinned by a national social protection policy or strategy. The third phase dates from around 2015, when social protection appeared in the SDGs, and focuses on trying to understand how and why social protection spread so rapidly as a development policy discourse. This paper contributes to this third, evolving strand of literature.

The burgeoning literature on social protection as a policy discourse connects with long-established theoretical and empirical literatures on social welfare in OECD countries (Esping-Andersen 1990; Schmitt and Starke 2012), on welfare provision in developing countries or the global South during and since the colonial period (Gough and Wood 2004; Midgley and Piachaud 2011; Schmitt 2015) and on cross-country policy transfer processes (Dolowitz and Marsh 2000; Dobbin, Simmons and Garrett 2007; Obinger, Schmitt and Starke 2013). Most relevant for the purposes of this paper is an emerging empirical literature, grounded in political science, that analyses the diffusion of social protection 
policies, specifically cash transfers, throughout the global South (von Gliszczynski and Leisering 2016; Leisering 2019), but often with a particular focus on sub-Saharan Africa (Adésínà 2011; Hickey et al. 2019).

Policy transfer is often understood as a benign or neutral process, whereby 'knowledge about policies, administrative arrangements and ideas in one political system (past or present) is used in the development of policies' administrative arrangements, institutions and ideas in another political system' (Dolowitz and Marsh 2000: 5). Posited causal mechanisms for policy transfer include learning, competition between neighbouring countries, and emulation or constructivism the tendency for diverse countries to mimic policies that have been socially constructed as desirable at the global level (such as free primary education or, in this context, social protection), even though adherence to these policies may be weak in practice.

A fourth causal mechanism in the policy transfer literature is coercion, which involves the use of power (e.g. financial leverage) by transnational actors to induce policy change by national governments. For example,

the International Monetary Fund (IMF), and the World Bank may shape policy in countries reliant on those entities for trade, foreign direct investment, aid, grants, loans... Coercion typically involves a change in incentives to nations, as when the World Bank conditions aid on fiscal austerity.

(Dobbin, Simmons and Garrett 2007: 454)

Obinger, Schmitt and Starke (2013: 115) call this 'coercive diffusion': 'An often mentioned case of coercive diffusion is financial aid linked to certain domestic reforms defined by donor countries and international institutions such as the International Monetary Fund or the World Bank'.

A soft form of 'coercive diffusion' is associated with the spread of hegemonic ideas through epistemic communities or policy entrepreneurs. 'Powerful countries with the research infrastructure, the critical intellectual mass, and welldeveloped connections between the policy world and various research nodes are unduly influential in the framing of policy discussions' (Dobbin, Simmons and Garrett 2007: 456).

This paper identifies a fifth mechanism - that I call 'policy pollination' - which is closely aligned to coercive diffusion and describes a particular process of policy transfer that, as argued below, underlies the rise of social protection in Africa. Cross-pollination in nature is the process by which pollen is carried from one flower to another by bees, birds, and other pollinators to fertilise the flower. For the purpose of this analogy, flowers are African countries, the pollen is social protection policies and pollinators are agents (staff, consultants) of international 
development agencies, literally flying from country to country to propagate social protection. Fertilisation is achieved when countries adopt social protection policies and programmes as advised by their pollinators. Policy pollination carries elements of all four mechanisms identified in the policy transfer literature (learning, competition, emulation, and coercion), but in donor-dependent countries the dominant driver is hard or soft coercion.

How have international development 'pollinators' spread the idea of social protection in Africa? How have they ensured that social protection programmes were implemented by African governments? How did they persuade 35 African governments to develop national social protection policies that are remarkably similar? This paper aims to provide answers to these questions, by defining the practice of 'policy pollination' and applying it to the diffusion of social protection across sub-Saharan Africa.

The next section introduces the notion of policy pollination as a development tactic, drawing on Africa's experience of structural adjustment in the 1980/90s, Poverty Reduction Strategy Papers in the early 2000s, and social protection since the early 2000s. Next, international development actors are identified as the leading pollinators in the social protection policy transfer process, dominated by three agencies: the ILO, UNICEF, and the World Bank. Five mechanisms of policy pollination are then discussed: (1) evidence-building; (2) financing; (3) capacity strengthening; (4) policy formulation; and (5) domestication of international law. Finally, I discuss why some African governments have resisted many years of pressure and inducements to adopt and scale up social protection in their country. 


\section{2. 'Policy pollination' as a development tactic}

International development agencies ${ }^{1}$ have intervened in social policy formulation in Africa since the colonial period and continue to do so today, decades after African countries achieved independence (Schmitt 2020). This has been achieved primarily through 'coercive diffusion', using the hard and soft power conferred by development finance - official development assistance (ODA), concessional lending and humanitarian relief - as leverage. In the 1980s, for instance, international financial institutions imposed conditions on structural adjustment loans that required African governments to, among other things, remove food price subsidies and impose user fees on poor citizens for health and education services. A striking feature of this set of 'Washington consensus' (Williamson 2000) policy prescriptions was their uniformity. A singular model for market liberalisation and state withdrawal, devised by a small but powerful group of development actors led by the Bretton Woods institutions (the World Bank and IMF), was implemented by a large number of African governments, almost always against their will, with consequences for poor Africans that were ambivalent at best and lethal at worst (Easterly 2006; Moyo 2009). ${ }^{2}$

In the early 2000s, a wave of Poverty Reduction Strategy Papers (PRSPs) spread across the global South, more than half being in Africa. In 2000 alone, 25 African governments prepared a PRSP document (IMF 2016). Again, this policy process was driven by the Bretton Woods institutions. Preparing a PRSP with World Bank and IMF support was rewarded with concessional loans or debt relief (Ejolu 2008). Significantly, all PRSPs embodied the same set of poverty reduction pillars, framed within a neoliberal ideology: 'good governance', pro-poor economic growth, investment in human capital and, in some cases, social safety nets to protect the poorest. The striking similarities in these documents across diverse countries reveals the extent to which they were designed by external actors following a boilerplate template, rather than emerging organically from domestic deliberative processes about optimal strategies for reducing poverty in each country context.

PRSPs were criticised as 'a primary policy device of international development institutions [that] restrict practical and political options, while exacting heavy 
establishment and compliance costs' (Craig and Porter 2003: 53). Easterly (2006: 127) argued that 'a PRSP is no substitute for democracy' and asserted that many PRSPs were effectively shoring up anti-democratic regimes and dictatorships. Compliance was enforced via the coercive application of conditionalities on loans by the international actors that designed PRSPs. However, their roll-out to dozens of low- and middle-income countries was represented by the IMF and World Bank as participatory and democratic. The IMF described the adoption of PRSPs as a country-driven process, 'promoting national ownership of strategies through broad-based participation of civil society' (quoted by Ejolu 2008: 22). Although PRSPs were implemented in more than 35 African countries, in recent years they have almost disappeared, confirming how shallowly grounded they were in domestic policy processes. ${ }^{3}$

As PRSPs faded into development policy history or were absorbed into the pillars of national growth and development strategies, so another wave of policy documents started spreading across Africa. Since 2010, 30 African countries have published a National Social Protection Policy (NSPP) or National Social Protection Strategy (NSPS) (Figure 2.1). These documents share many common features. Notably, they all include promises that the government will deliver social assistance to specified target groups: children, older persons, and other vulnerable groups as well as 'the poor' (UNDP 2019: 56). As discussed later, these policy statements have been heavily influenced - financed, commissioned and/or (co-)authored - by international development agencies.

As Figure 2.1 reveals, the number of African countries with a NSPP or NSPS multiplied from just five in 2010 to 35 in 2019. It is difficult to believe that this is a coincidence - that more than half the governments in Africa spontaneously and independently decided to introduce a social protection policy or strategy within a few years. So how did this happen? Are NSPPs the new PRSPs? Can social protection be modelled as a new wave of 'policy pollination', led by development agencies using the leverage of development finance and imposed on - rather than chosen by - African governments? 


\section{Figure 2.1 New national social protection policies or strategies in Africa by year, 2000-2019}

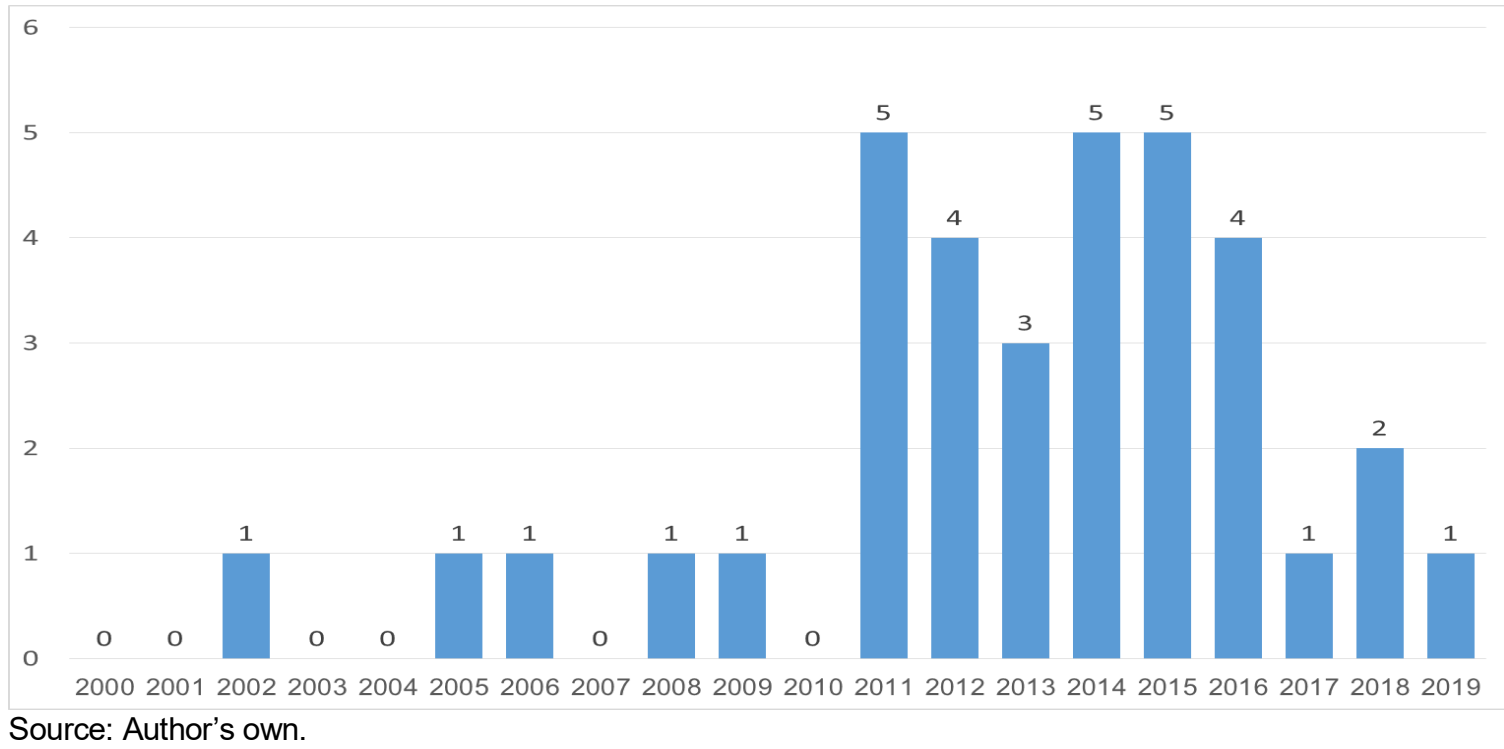

A revealing statement by two United Nations Special Rapporteurs highlights both the disproportionate power that international institutions exercise over social policy formulation in poor countries, and the contradictions between the harsh Washington consensus policies that were imposed in the 1980s (e.g. making poor people pay for education and health care) and the expansionist social protection policies (notably giving free cash to poor people) that were advocated by the same institutions in the 2000s.

In the past, major international institutions have pushed States to lower government spending and programming in favour of economic development, opening markets and reducing the size of the State. In the last decade however, many international institutions have begun to address the benefits of social protection systems to development and to promote their adoption.

(de Schutter and Sepúlveda 2012: 3)

As with PRSPs, the story of social protection's rapid rise in Africa is interpreted differently by different observers, some seeing it as a success for African governments, others as a triumph for international development actors. This can perhaps be represented as two stylised narratives. 


\section{The 'national ownership' narrative: Social protection in Africa is a} success story for African social policy in the early twenty-first century. Almost two in three African countries now have a national social protection policy or strategy, from a baseline of zero in 2000. Large-scale nationally administered social protection programmes have been introduced and rolled out to millions of people, notably the Child Support Grant in South Africa (launched in 1998, reaches 12 million children), Productive Safety Net Programme in Ethiopia (launched in 2005, reaches 9 million people), Vision 2020 Umurenge Programme in Rwanda (launched in 2008, reaches 150,000 households), Livelihood Empowerment Against Poverty in Ghana (launched in 2008, reaches 150,000 people), among many others (UNDP 2019). Several governments in Africa now have social protection ministries, agencies, and laws.

\section{The 'donor-driven' narrative: Social protection in Africa is a success} story for the international development community in the early twentyfirst century. The development industry (United Nations agencies, bilateral and multilateral donors, international financial institutions, international NGOs, development consultants, management consortia, research institutes) has vigorously 'pollinated' social protection throughout Africa. National policies do not necessarily imply national ownership. Government commitment to social protection is variable across the continent, being generally lower in the poorest aid-dependent countries, where national social protection strategies are conceived and often drafted by international consultants and most social protection programmes have been designed, financed and evaluated by development agencies and their agents.

Support for both these positions can be found in the social protection literature. In 2010, an influential book titled Just Give Money to the Poor presented social cash transfers in its sub-title as The Development Revolution from the Global South (Hanlon, Barrientos and Hulme 2010; emphasis added), implying that the idea is indigenous rather than imported. By contrast, an article published in the Journal of Social Policy in 2016 was subtitled How International Organizations Defined the Field of Social Cash Transfers in the 2000s (von Gliszczynski and Leisering 2016).

Does it matter which of the above (simplified) narratives is a closer approximation to the truth? Perhaps both are true, and social protection is a success story for governments, international agencies, and the African poor: a 'win-win-win'. Surely what matters is that poor people receive assistance that alleviates their poverty, protects them against risks and shocks, reduces their food insecurity and facilitates their access to essential services like education and health care? This is the 'bottom line', but it also matters which narrative is true, because if the second narrative is closer to reality than the first then 
questions of domestic commitment and sustainability become crucial. What would happen if the donors withdraw, or shift their focus and spending to another policy agenda? How much of their heavy investments in building social protection capacity in countries across Africa would remain? 


\section{International development agencies as 'policy pollinators'}

Social protection as a development policy discourse emerged out of social safety nets, a limited set of instruments that straddled the gap, rather uneasily, between social assistance and humanitarian relief. The 1990 World Development Report set out a two-pronged strategy for reducing poverty: labour-intensive economic growth, and provision of basic social services to the poor. The report also identified the need for safety net programmes, as a complementary third element.

Even if this basic two-part strategy is adopted, many of the world's poor - the sick, the old, those who live in resource-poor regions, and others will continue to experience severe deprivation. Many others will suffer temporary setbacks owing to seasonal variations in income, loss of the family breadwinner, famine, or adverse macroeconomic shocks. A comprehensive approach to poverty reduction, therefore, calls for a program of well-targeted transfers and safety nets as an essential complement to the basic strategy. (World Bank 1990: 3; emphasis added)

This is possibly the first articulation in the development policy discourse of what later became the two building blocks of social protection systems in the global South: targeted transfers or social assistance to the chronically poor (who 'experience severe deprivation') and categorical vulnerable groups ('the sick, the old'), as well as safety nets or social insurance for those experiencing livelihood shocks ('temporary setbacks'). ${ }^{4}$ In the late 1990s, the World Bank developed the safety nets component into its 'Social Risk Management' framework (World Bank 2001), and it continues to use the term 'safety nets' even though it is out of favour with other agencies. As recently as 2018, the World Bank published the third edition of The State of Social Safety Nets (World Bank 2018).

In 2000 , social protection effectively did not yet exist in the development policy discourse. The period since has been framed by two global position statements about development policy: the Millennium Development Goals (MDGs) and the Sustainable Development Goals (SDGs). With hindsight, it seems incredible that the MDGs did not contain a single mention of social protection. Just 15 years later, social protection consolidated its entrenchment in the international development policy discourse by being explicitly named in three of the 17 SDGs, 
as a mechanism for ending poverty (Goal 1), enhancing gender equality and empowerment (Goal 5) and reducing inequality (Goal 10). ${ }^{5}$

2012 was another watershed year for social protection. Three international development agencies - the ILO, UNICEF, and World Bank - had emerged as the leading actors in this sector in the global South. It was increasingly clear that social protection was here to stay; it was not a development policy experiment or fad that would disappear after a few years. Coincidentally, these agencies each released definitive statements of their approach to social protection in the same year.

In June 2012, the International Labour Conference endorsed a Recommendation Concerning National Floors of Social Protection, which presented an explicit rights-based approach to social protection, building on the Universal Declaration of Human Rights of 1948. The Recommendation defined social protection floors as 'nationally defined sets of basic social security guarantees which secure protection aimed at preventing or alleviating poverty, vulnerability and social exclusion' (ILO 2012). 'The guarantees should ensure at a minimum that, over the life cycle, all in need have access to essential health care and to basic income security' (ILO 2012). The four guarantees are:

1. Basic income security for children;

2. Basic income security for persons in active age unable to earn sufficient income;

3. Basic income security for persons in old age;

4. Access to a set of goods and services constituting essential health care including maternity care.

In effect, this set of provisions elaborates and gives rights-based effect to the underdeveloped social assistance component of social protection systems, since the Social Security (Minimum Standards) Convention 60 years earlier had focused mainly on social insurance.

Also released in 2012, UNICEF's Social Protection Strategic Framework (UNICEF 2012) identified three principles for 'integrated social protection systems': progressive realisation of universal coverage; nationally owned systems and national leadership; and inclusive social protection - tackling social exclusion. The specific focus of UNICEF's engagement with social protection is

Goal 1, Target 3 - End poverty: Implement nationally appropriate social protection systems and measures for all, including [social protection] floors.

Goal 5, Target 4- Gender equality and empowerment: Recognise and value unpaid care and domestic work through the provision of public services and social protection policies.

Goal 10, Target 4 - Reduce inequality: Adopt policies, especially fiscal, wage and social protection policies, and progressively achieve greater equality (United Nations 2015). 
revealed in the subtitle: Enhancing Equity for Children. While this naturally reflects UNICEF's mandate as the United Nations agency for children, it also leads UNICEF to favour a certain set of policy instruments and to prioritise some vulnerable or 'at risk' groups above others.

UNICEF's vision of a social protection system has four components (UNICEF 2012):

1. Social transfers: Predictable direct transfers to individuals or households, both in-kind and in cash, to protect against shocks and support accumulation of human, financial and productive assets.

2. Ensuring access to services: Interventions that reduce economic and social barriers to basic social services.

3. Social support and care services: Human resource-intensive services that identify and reduce vulnerability and exclusion.

4. Legislation and policy reform: Changing policies and legislation to remove inequalities in access to services and/or economic opportunities, addressing issues of discrimination and exclusion.

Significantly, the World Bank's Social Protection and Labor Strategy (World Bank 2012) links social protection directly to labour markets: 'social protection and labor systems... help people and families find jobs, improve their productivity, cope with shocks, and invest in the health, education, and well-being of their children'. The subtitle - Resilience, Equity, and Opportunity - highlights that the World Bank sees social protection as performing instrumental functions, beyond being a right or entitlement. It should contribute to building resilience and generate opportunities to escape from poverty, such that beneficiaries will become self-reliant and resilient and ultimately no longer need social assistance.

The World Bank strategy has three overarching goals:

1. 'Improve resilience by helping people insure against drops in well-being from different types of shocks'.

2. 'Improve equity by reducing poverty and destitution and promoting equality of opportunity'.

3. 'Promote opportunity by building human capital, assets, and access to jobs and by freeing families to make productive investments because of their greater sense of security'. 
The strategy envisages a linear progression to building social protection and labour systems, starting with a few uncoordinated projects towards fully connected, well-functioning and efficiently run programmes. 'The strategic direction is to help developing countries move from fragmented approaches to more harmonized systems for social protection and labor'. With this framing, the main prongs of the World Bank's strategy are social assistance, social insurance, and active labour market programmes (Robalino et al. 2012):

1. Social assistance: cash transfers; food programs; public works.

2. Social insurance: unemployment benefits; health insurance; disability pensions; survivors' pensions; old-age pensions.

3. Active labour market programmes: intermediation; counselling; job search and matching; vocational skills training; wage subsidies to firms.

While social assistance programmes in particular have proliferated throughout Africa (UNDP 2019), many with World Bank financial and technical support, social insurance has received less attention and active labour market programmes have disappointed. A recent review of evaluations concluded that 'active labor market policies are much less effective than policymakers typically assume. Many of these evaluations find no significant impacts on either employment or earnings' (McKenzie 2017).

These position statements by three of the most influential international development agencies are important because they define the focus and parameters of each agency's engagement with, and support for, social protection policies and programmes in the countries where they operate - where they exercise substantial influence over policymaking processes, using mechanisms that are discussed next. 


\section{4. 'Policy pollination' mechanisms}

The international development community (not only the ILO, UNICEF, and World Bank, also DFID, FAO, GIZ, UNDP, WFP and many others) have invested heavily in promoting social protection in Africa since 2000, using various mechanisms. Five are discussed here: (1) building the evidence base for social protection impacts; (2) financing social protection programmes and systems; (3) strengthening government technical and operational capacity; (4) instigating national social protection policies; and (5) domesticating international law.

\subsection{Building the evidence base}

In the early 2000s the international development community settled on 'social cash transfers' (SCTs) as their preferred modality for social protection in lowand middle-income countries. The UK's Department for International Development (DFID) set out the theoretical case for delivering cash transfers to poor people.

While poverty is multi-dimensional, low and variable income is central to the problem. Modest but regular income from cash transfers helps households to smooth consumption and sustain spending on food, schooling and health care... Over time, transfer income can help households to build human capital [and] save up to buy productive assets... Cash transfers can thus both protect living standards (alleviating destitution) and promote wealth creation.

(DFID 2011: i)

However, the evidence base at first was thin. There were few regular social cash transfer programmes in low-income countries, and even fewer that had been rigorously evaluated. There was a growing body of credible evidence from Latin America about the positive impacts of conditional cash transfer programmes (Fiszbein and Schady 2009; Adato and Hoddinott 2010), but very little evidence from sub-Saharan Africa about unconditional cash transfers. A large part of the initial effort by development partners to persuade governments in Africa to introduce or expand social protection was investment in building the evidence base that unconditional cash transfers can in fact protect and promote living standards. The implicit theory of change is that policy adoption is an evidencedriven process. Proving that social protection can contribute to desired outcomes such as poverty reduction would convince African governments to implement and pay for their own national social protection programmes. 
From the very first cash transfer pilot projects in Africa, therefore, development agencies allocated funds to monitoring and evaluation (M\&E), especially of projects that they instigated and financed. The technical justification for conducting impact evaluations is to confirm that a policy intervention is achieving its objectives, and to generate learning for improved design or delivery, to enhance impacts and cost-effectiveness. However, development agencies also commission evaluations of interventions they support for advocacy reasons, aimed at two distinct audiences.

First, international agencies need to justify their spending on development programmes to their domestic constituencies back home. Demonstrating 'value for money' and showing positive impacts - in terms of, say, reductions in poverty or child malnutrition - is strategically necessary to keep the pipeline of development assistance flowing. Cash transfer projects are self-contained interventions with immediate and easily demonstrable benefits, which allows agencies to claim impacts such as lifting thousands of poor Africans out of poverty, as their direct and attributable achievement. More broadly, pilot projects offer opportunities for donor agencies to stamp their logo on reports that quantify their contribution to a range of desirable development outcomes in low- and middle-income countries. Such evidence of success leverages further rounds of funding from development agencies, which is underwritten by taxpayers in highincome countries. The ongoing surge in externally supported social assistance programmes in Africa suggests that the evidence is persuasive, at least to the international development community.

Second, as noted, international agencies commission impact evaluations of 'their' projects for advocacy purposes in countries where they work, as an integral part of the 'policy pollination' strategy. Specifically, findings of positive impacts of SCTs were intended to convince African governments to adopt and scale up poverty-targeted cash transfer programmes. For this reason, even small-scale pilot projects received disproportionately large evaluation budgets, from which generalisations were extrapolated about SCTs as a modality for delivering social protection in Africa. Pilot projects were actually preferred to national programmes for the first generation of evaluations, for several reasons:

1. Control groups could easily be drawn from equally poor and technically eligible people within the same community or in neighbouring communities. Ethical concerns about preferential treatment for beneficiaries and exclusion of equally needy control group households were countered with the 'roll-out' argument: this year's control group could become next year's beneficiaries.

2. Pilot projects are small enough that representative samples can be drawn to demonstrate statistically significant impacts. The fact that pilot projects by definition create massive exclusion by design (or under-coverage) was justified as transitional - once governments see the evidence that the 
programme works they will choose to support it, finance it and expand coverage to all eligible individuals or households at the country level.

3. Pilot projects allow experimentation to test different design and implementation modalities. In Lesotho's Cash and Food Transfers Pilot Project, some beneficiaries received food packages, some received cash transfers, and some received both cash and food. In Kenya's Hunger Safety Net Programme, three discrete targeting mechanisms determined eligibility in different communities: households with high dependency ratios, communitybased wealth ranking, or older persons (Sabates-Wheeler et al. 2015).

4. Pilot projects have fixed budgets and predetermined exit strategies, whereas most national social protection programmes are more expensive by an order of magnitude and are implemented on a long-term or permanent basis longer than donors can commit to, given their $1-5$ year project cycles.

The UK development agency explicitly acknowledged the link between building the evidence base and building political support for cash transfer programmes. 'Robust monitoring and evaluation are crucial both for programme performance and political sustainability. The rapid spread of cash transfers in MICs in recent years has been in large part due to just such high-quality analysis and M\&E' (DFID 2011: vii).

The first decade of this century saw a rapid accumulation of evidence that social protection in Africa, specifically cash transfers, 'works'. However, first generation evaluations were not always rigorous. A GTZ-funded evaluation of the influential Pilot Social Cash Transfer Scheme in Kalomo District, Zambia found improvements for beneficiary households in several indicators relative to baseline, including food security, livelihoods, and asset ownership (MCDSS and GTZ 2007). However, this study and others were rightly criticised for not including a control group, which meant that findings of positive changes in beneficiaries' wellbeing could not be unambiguously attributed to the SCT scheme.

There were also other problems. First, any intervention that gives cash to poor households makes them better off by definition, so counting household assets and consumption before and after they receive project benefits is measuring short-term programme effects, not sustainable programme impacts. It was far from clear that gains recorded would be sustained after the project ended, which exposed these 'baseline to endline' evaluations to accusations of inflated claims about their long-term impacts on indicators such as poverty and asset ownership. Second, coverage of these first generation SCT projects was tiny the Kalomo SCT pilot reached only 1,027 households when it was evaluated in 2007 - and it is easier to get impressive results working with a thousand beneficiaries than with millions. Related to this, positive outcomes were 
reinforced by the intensive support and attention provided by NGO workers operating at community level, but scaling up these projects and transferring them to national governments requires entirely different management models and financing modalities, and raises more complex sets of challenges.

Early attempts were made to synthesise the accumulating experience and evidence with various forms of social protection programmes across African countries. In 2005, UNICEF commissioned Save the Children UK, HelpAge International and the Institute of Development Studies to compile 'lessons from cash transfer schemes in east and southern Africa for supporting the most vulnerable children and households' (Devereux et al. 2005). In 2007, DFID commissioned a Review of Evidence and Evidence Gaps on the Effectiveness and Impacts of DFID-Supported Pilot Social Transfer Schemes (Devereux and Coll-Black 2007). In 2009, a book was published titled Social Protection in Africa (Ellis, Devereux and White 2009) that presented 15 case study programmes from six countries, drawing on research commissioned by the Regional Hunger and Vulnerability Programme (RHVP). RHVP was a donor initiative, funded by two bilateral agencies - the UK's DFID and the Australian Agency for International Development (AusAID) - that explicitly linked evidence-building to policy advocacy (see Box 4.1).

Following these first generation social protection initiatives, a more sophisticated wave of impact evaluations was commissioned of larger projects and programmes such as the Productive Safety Net Programme (PSNP) in Ethiopia, the Hunger Safety Net Programme (HSNP) in Kenya, and Concern Worldwide's 'Graduation model' projects in Burundi and Rwanda. Multi-year multi-round household surveys were designed (baseline, midline, endline, sometimes also a follow-up) with treatment and control groups, following rigorous quasi-experimental randomised control trial (RCT) protocols.

In 2011, DFID published an Evidence Paper on cash transfers in developing countries. Key findings synthesised from available evidence at the time included the following (DFID 2011: ii-iii):

- 'Cash transfers can reduce inequality and the depth or severity of poverty'.

- 'Cash transfers might support "graduation" from poverty for those of working age'.

- 'Cash transfers have leveraged sizeable gains in access to health and education services'.

- 'Cash transfers help to strengthen household productivity and capacity for income generation'.

- 'The introduction of cash transfers into poor, remote areas can stimulate demand and local market development'. 
- 'Transfers are likely to contribute to long-term growth by raising the human capital of the next generation'.

- 'Transfers can influence gender relations and empower the poor'.

\section{Box 4.1 Regional Hunger and Vulnerability Programme}

From 2005 to 2011, RHVP worked in six countries of southern Africa (Lesotho, Swaziland, Malawi, Mozambique, Zambia, and Zimbabwe), compiling evidence of successful social protection initiatives and disseminating these lessons across the six countries to promote uptake of 'best practice'.

RHVP activities reflected a simple 'policy influencing' model: 'Evidencebuilding + Capacity-building = Positive policy change'. In other words, providing evidence that social protection works plus building government capacity - through technical assistance, study tours, training courses, policy workshops, etc. - should lead to adoption of social protection by national governments. Under its Regional Evidence-Building Agenda (REBA), RHVP commissioned international and national researchers to analyse social protection programmes in each country. These were compiled and published in a book called Social Protection in Africa, with thematic chapters (targeting, delivery, coverage, cost-effectiveness, etc.) and 15 case study chapters.

An intriguing feature of the 15 case studies is their diversity. Apart from five cash transfer programmes, including a social pension and a 'food subsidy' delivered in the form of cash, the case studies included a public works project, a school feeding scheme, agricultural input subsidies, education material fairs, 'neighbourhood care points' and 'chief's fields' for vulnerable children, and small livestock transfers.

Although public works and school feeding remain on the social protection agenda, development agencies dislike and discourage subsidies, while indigenous ideas like neighbourhood care points and chief's fields have disappeared. Since Social Protection in Africa was published, the international discourse on social protection in Africa has converged around social cash transfers, to the neglect and marginalisation of most other instruments. 
Five years later, DFID commissioned a 'rigorous review' of cash transfer impacts from the Overseas Development Institute (ODI). By 2016, the evidence base had grown substantially. The ODI review reinforced and added nuance to theoretical predictions and earlier findings. Summarising the impacts reported in 165 evaluations of 56 cash transfer programmes in low- and middle-income countries, Bastagli et al. (2016) found 'strong evidence' that cash transfers are associated with increases in:

- Total household expenditure (a proxy for reductions in monetary poverty);

- Food expenditure and dietary diversity (indicators of food security);

- School attendance (but not necessarily improved learning outcomes);

- Use of health services;

- Investment in livestock;

- Household savings;

- Women's decision-making power.

In cases where cash transfers did not significantly reduce monetary poverty, Bastagli et al. speculate that this was probably because transfer amounts were inadequate or the programme duration was too short. In cases where education and health outcomes did not improve, Bastagli et al. point to the need to invest in quality of services - cash transfers can only stimulate demand for these services.

Very few evaluations in the ODI review found significant positive impacts on children's malnutrition (i.e. anthropometric indicators such as stunting and underweight), probably because the determinants of nutrition status are multiple and cash transfers impact mainly on food intake, not necessarily on other determinants such as diet quality, childcare practices (e.g. breastfeeding), water quality and access to sanitation facilities.

Almost all the evidence assembled in these books and reports derives from evaluations that focus narrowly on changes in the material wellbeing of beneficiaries over a short period of time, bounded by and limited to their participation in one social protection programme. Very few of these studies consider the social and psychosocial impacts of these programmes, and almost none situates the intervention in its broader socio-political context, not even by considering the confounding effects of synergies or conflicts between the intervention and existing government programmes. These decontextualising and time-bound parameters allow the positive impacts of these programmes to be exaggerated and potential negative side-effects (such as stigma and social exclusion) to be overlooked. 
Empirical evidence that giving money to poor people in Africa leaves them better off than before has been presented in hundreds of research reports and journal articles, and synthesised in several overview publications since 2010, including:

1. Cash Transfers Evidence Paper. Written by staff in the Policy Division of DFID. 'This paper provides a synthesis of current global evidence on the impact of cash transfers in developing countries, and of what works in different contexts... While the primary purpose of cash transfers is to reduce poverty and vulnerability, the evidence shows that they have proven potential to contribute directly or indirectly to a wider range of development outcomes' (DFID 2011: i).

2. The Cash Dividend: The Rise of Cash Transfer Programs in sub-Saharan Africa. A book written by a World Bank economist and a World Bank consultant. 'In 2009, growing interest in the use of CT programs in subSaharan Africa led the World Bank to initiate a comprehensive desk review of the CT programs that had been used recently in the region. This book presents the results of the review' (Garcia and Moore 2012: 2).

3. Social Protection for Africa's Children. An edited book published with financial support from DFID and UNICEF. 'This book includes both "quantitative" and "qualitative" studies of social protection in Africa that either target children directly or have significant impacts on children's well-being' (Handa, Devereux and Webb 2011: 7).

4. Cash Transfers: What Does the Evidence Say? A rigorous review commissioned by UK Aid from the Overseas Development Institute. 'This review retrieves, assesses and synthesises the evidence on the effects of cash transfers on individuals and households through a rigorous review of the literature of 15 years, from 2000 to 2015' (Bastagli et al. 2016: 5).

\section{From Evidence to Action: The Story of Cash Transfers and Impact} Evaluation in sub-Saharan Africa. An edited book that was a product of the Transfer Project, co-funded by FAO and UNICEF. 'Evidence on the effectiveness of unconditional cash transfers provided through government programmes in SSA has not been substantially documented... One key objective of this book is to provide an overview of this accumulated evidence' (Davis et al. 2016: 1).

6. Realizing the Full Potential of Social Safety Nets in Africa. A World Bank report in its Africa Development Forum series. 'This report first presents a snapshot of social safety nets in Africa and the mounting evidence for the effectiveness of these programs in promoting the well-being and productive inclusion of the poorest and most vulnerable' (Beegle et al. 2018: 2). 


\section{The State of Social Assistance in Africa. A report produced by UNDP in} collaboration with other UN agencies and the African Union. 'The motivation behind this report and data platform has been to provide African policymakers, civil servants, researchers, development practitioners and civil society a comprehensive overview of social assistance in Africa across its legal, financing and institutional dimensions' (UNDP 2019: 11).

None of these publications is a product of 'blue skies' academic research; they were written or commissioned by international development agencies for advocacy purposes, to promote specific policy positions. The Foreword to From Evidence to Action states: 'These pages also document the ways in which the Transfer Project has influenced the policy debate in each of the eight countries' (Davis et al. 2016: vi). While the primary intended impact of cash transfer projects is to improve the wellbeing of beneficiaries, the primary intended impact of cash transfer evaluations is to convince governments to implement and finance national cash transfer programmes.

Interestingly, the claims for positive impacts of social protection in Africa draw from a very narrow evidence base - about a dozen mostly anglophone former British colonies in East and Southern Africa, plus the anglophone former British colony of Ghana in West Africa. The book Social Protection in Africa (Ellis, Devereux and White 2009) has case studies from only six countries. ${ }^{6}$ Social Protection for Africa's Children (Handa, Devereux and Webb 2011) presents evidence from seven countries. ${ }^{7}$ From Evidence to Action: The Story of Cash Transfers and Impact Evaluation in sub-Saharan Africa (Davis et al. 2016) has eight country case studies. ${ }^{8}$ This is not just a small selection (11 out of Africa's 55 countries), it is also heavily overlapping: eight of the 11 countries are represented in at least two of these books, while Malawi and Zambia feature in all three.

A high proportion of SCT programmes in Africa have now been rigorously evaluated, some several times, often applying RCT principles (difference-indifferences between control and treatment groups from baseline to endline). Most or all of these evaluations have been commissioned and paid for by international agencies, rather than the governments of the countries where these programmes are implemented, and they have been conducted by research institutes and consultancy firms from Europe and North America. Very rarely are evaluations led by African researchers or consultants, though African partners are usually subcontracted to perform functions such as data collection. The most evaluated programme in Africa is Ethiopia's PSNP, which implemented a mixed methods longitudinal evaluation over a 14-year period from 2006 to 2018, with 
about 3,000 participants plus control households re-interviewed every two years. The survey was administered by the Ethiopian Central Statistical Agency, and the World Bank commissioned the International Food Policy Research Institute (IFPRI) and IDS to conduct these evaluations, with in-country support from Dadimos Development Consultants (Sabates-Wheeler et al. forthcoming).

Conversely, most government-owned social protection programmes in Africa are weakly monitored and almost never evaluated, either by governments or by development agencies. Why is this the case? Possibly because national governments and their international development partners have different agendas in supporting social protection. African governments have little incentive to undertake evaluations of their own programmes. They might argue that if social protection is their mandate as part of an implicit 'social contract' between citizens and the state, then delivering social assistance and social insurance is all that matters - there is no need to quantify the positive impacts of these programmes on poverty or any other outcomes. On the other hand, development agencies have no incentive to evaluate government programmes because they (the agencies) cannot claim the credit for positive impacts. For these reasons, government programmes tend to be under-evaluated while donor-funded projects tend, if anything, to be over-evaluated. This asymmetry confirms that building the evidence base for donor-supported social protection in Africa is primarily an advocacy agenda.

\subsection{Financing social protection programmes}

Many countries in Africa were initially reluctant to introduce social protection programmes, for two main reasons: 'dependency syndrome' and unaffordability. First, governments feared that giving money to poor people would undermine their community-based informal support systems and create dependence on 'handouts' from the state. Empirical evidence for these concerns is lacking, not least because the cash transfers delivered in African countries are too small to disincentive recipients from working to earn an income (Shepherd et al. 2011). Nonetheless, this perception persists, sometimes reinforced by pejorative beliefs about the poor (e.g. that they would 'drink the money'). This partly explains the resistance of some African governments to introduce unconditional cash transfers (as discussed later), despite consistent pressure and financial incentives from international agencies.

Second, African governments often see social protection as unaffordable, given fiscal constraints and competing priorities for public spending (Seekings 2017). In particular, cash transfers at scale are regarded as too expensive, especially if they involve regular transfers of meaningful amounts of cash to all people defined as poor in the country every month, not only for a year or two but indefinitely. 
One response to the reality of limited budgets and low prioritisation of social protection in much of Africa was for external actors to provide the seed funding themselves, especially for technical inputs such as design and systems-building, but also, in cases of small-scale pilot projects, for cash transfers. However, this was intended to be an interim measure until governments assume responsibility for running and financing these projects as national programmes. The anticipated shift in financing from external to national sources can be illustrated as a 'funding seesaw'. Figure 4.1 has been turned sideways to illustrate this effect across countries rather than in a single country over time, with dark bars representing the proportion of social assistance spending that is 'donor-funded' and light bars showing the proportion that is government-funded. All social assistance spending (100 per cent) in the seven countries on the left (including Ethiopia, Somalia and South Sudan) is donor-funded and all social assistance spending in the six countries on the right (including Botswana, Namibia, and Mauritius) is domestically funded. In countries falling between these two extremes (from Guinea-Bissau to Senegal) the balance between external and domestic financing varies from 90:10 to 10:90.

\section{Figure 4.1 Share of donor and government funding of social assistance in sub-Saharan Africa}

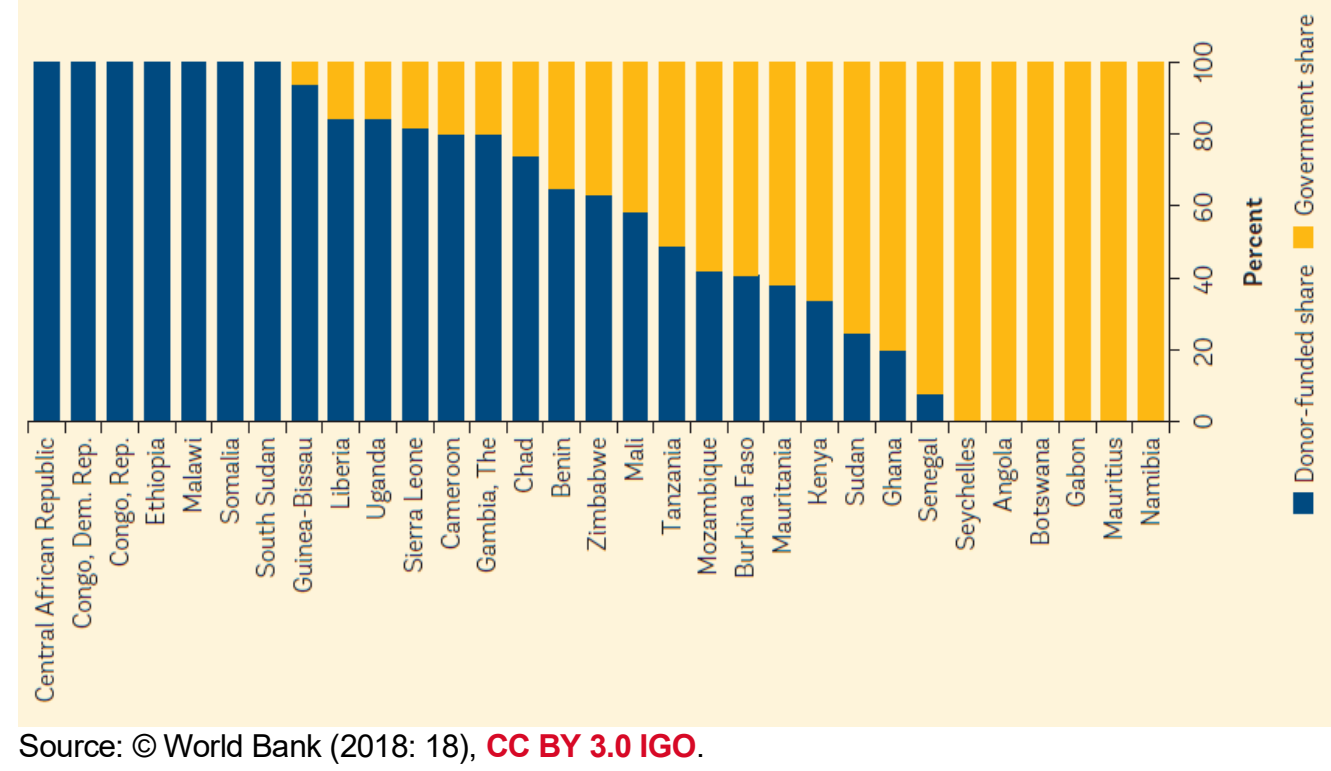

It is striking that the countries where social protection is fully funded by external actors are some of the world's poorest and most aid-dependent economies. Conversely, all the countries where social protection is fully funded out of domestic resources are middle- or high-income economies. ${ }^{9}$ This provides empirical evidence for a familiar dilemma - that countries with the greatest need 
for social protection have the least resources to deliver it - and offers a justification for external actors stepping in to fill the financing gap. One characteristic of low-income economies is a small proportion of people who are formally employed and paying income tax that government can collect and allocate to social protection. Sub-Saharan Africa has 'the smallest proportion of working-age population in the world' (ILO 2017: 130) and high levels of economic informality, therefore a very small tax base. The 'funding seesaw' predicts that as national incomes rise, governments will take on increasing responsibility for financing their social protection programmes, which also allows them to take more control over social protection design and delivery. Until then, development agencies will continue to offer full or partial funding of social protection in lowincome African countries, and they will continue to exploit this leverage by shaping social protection in these countries to reflect their own mandates and objectives.

A second response by external actors to claims that social protection is unaffordable in poor countries was to downplay moral or rights-based arguments and present an economic argument instead: the 'business case' for 'investment' in social protection. This required demonstrating that public spending on social protection generates economic returns to individual beneficiaries, local economies, and the national economy. Pathways from social transfers to economic growth include human capital formation (this explains why the World Bank promotes conditional cash transfers that require beneficiaries to send their children to school and health clinics) and local income multipliers (because cash transfers stimulate demand for goods and services). FAO applied a methodology called LEWIE (Local Economy Wide Impact Evaluation) to simulate the multiplier effects of cash transfer programmes (Thome et al. 2016). The Economic Policy Research Unit (EPRI) used a microsimulation model showing how investment in social protection contributes to economic growth, reducing poverty and requiring less social protection in the future (Samson 2005). The UK and Australian aid agencies each commissioned reviews of the effects of social protection on economic growth (Barrientos and Scott 2008; Mathers and Slater 2014; respectively). While these initiatives might be characterised as contributions to the evidence-building agenda rather than the financing debate, its primary purpose was advocacy - challenging the perception that social protection is wasteful or unproductive expenditure that low-income countries cannot afford.

Related to this 'social protection as an investment' argument was work demonstrating that social protection can generate 'value for money' (VfM) for governments as well as agencies, where VfM is analysed in terms of costefficiency and cost-effectiveness against policy objectives such as poverty reduction. DFID commissioned studies of 'measuring and maximising value for money' in social transfer programmes (White et al. 2013) and in social protection systems (White et al. 2015). As their titles indicate, this pair of manuals offers 
guidance on how to assess whether social protection programmes and systems are actually reducing poverty and inequality, and how to achieve these goals more cost-efficiently and more cost-effectively.

Cost-efficiency for social protection systems is about ensuring that planned outputs of the right quality are produced at the lowest possible cost... Cost-effectiveness is about achieving system outcomes and impacts at the lowest possible cost. The focus in lowincome countries is most often on cost-effectiveness in reducing extreme poverty and inequality... Ex ante analysis of costeffectiveness in terms of impacts on poverty is a standard feature in the appraisal section of business cases for social protection programmes.

(White et al. 2015: x, 19)

A third response by external actors was to point out that public spending decisions are political choices, not an inflexible technical rule, and that even the poorest countries can afford some spending on social protection. The World Social Protection Report 2017-19 reveals that spending on social protection as a percentage of GDP averages just 4.5 per cent in sub-Saharan Africa, but 18 per cent in Western Europe (ILO 2017). It follows that African countries should allocate more to social protection, because poverty is lowest in countries that spend the most on social protection. Responding to complaints that resources simply are not available, the ILO produced guidelines showing governments how they can create more fiscal space for social protection. Options include:

1. 'Reallocating public expenditures;

2. Increasing tax revenues;

3. Expanding social security coverage and contributory revenues;

4. Lobbying for aid and transfers;

5. Eliminating illicit financial flows;

6. Using fiscal and foreign exchange reserves;

7. Borrowing or restructuring existing debt, and;

8. Adopting a more accommodative macroeconomic framework' (Ortiz et al. 2015: ii).

ILO's research draws on empirical data and country case study experiences, but once again it was undertaken explicitly for advocacy purposes, to persuade 
governments that they can (and should) spend more on social protection than they do already.

Despite all these efforts, the question of who finances social protection programmes remains a contested issue between international organisations and many African governments. As Seekings (2017: ii) explains:

International organizations have generally failed to convince national policy-making elites to raise and to allocate scarce domestic resources to social protection programmes. The result is an 'affordability gap' between what is advocated for African countries and what these countries' governments are willing to spend.

\subsection{Strengthening capacities to deliver social protection}

International agencies have invested heavily in building the capacity of governments in Africa to design and implement social protection programmes, and to strengthen social protection systems in their countries. This investment has taken several forms, including embedding expatriate consultants as advisors within relevant government ministries and agencies, arranging study tours for politicians and technical staff to observe and learn from social protection practices in other countries, and facilitating events such as high-level dialogues with parliamentarians or regional bodies such as the African Union.

But the most popular capacity-building mechanism has been training workshops, where government officials from a single country or region, or across the world, come together for a period between one day and two weeks, to learn about social protection theory and practice from designated experts. The workshop setting also allows agencies delivering the training to imprint their preferred approaches to social protection on participants, through the positions taken by trainers in relation to controversial aspects, such as conditionalities and targeting. For instance, while the World Bank favours conditional cash transfers and poverty targeting using proxy means tests (to identify the poor), the ILO and UNICEF prefer unconditional cash transfers and categorical targeting (e.g. children and older persons). These preferences reflect fundamentally different visions of social protection.

Two leading social protection agencies run their own training workshops: the ILO and the World Bank. The World Bank has run an annual training course in Washington since the early 2000s, now called the Social Safety Nets and Delivery Core Course, which attracts policymakers, analysts and operational staff from international agencies (including the World Bank itself) and NGOs. This course 'aims to provide participants with an in-depth understanding of the 
conceptual and practical issues on safety nets or social assistance as part of broader social protection systems'. ${ }^{10}$ One session in the 2019 course was called 'Making the case for social safety nets', confirming that the pedagogical objective is 'policy pollination' as much as being purely educational.

The ILO runs an Academy on Social Security every year at its International Training Centre in Turin. This two-week course offers 'a diversified training package on governance and financing, reforms and extension of social protection systems'. ${ }^{11}$ Responding to Covid-19, several modules are now available online, including E-Coaching on Social Protection: Towards Responsive Systems and E-Learning on Impact Assessment for Social Protection Analysts. ${ }^{12}$

Online training is also available through TRANSFORM, an inter-agency initiative led by ILO, UNICEF and UNDP and hosted by the 'Virtual Campus' of socialprotection.org. TRANSFORM - Leadership \& Transformation Curriculum on Building and Managing Social Protection Floors in Africa - explicitly promotes the ILO's preferred approach: 'By the end of this course, you should be able to understand why and how a Social Protection Floor is beneficial to your specific country context and how it can assist social and economic development'. ${ }^{13}$

From 2007-19 the EPRI, in collaboration with the Centre for Social Protection (CSP) at IDS and Maastricht University, ran a two-week advertised course twice each year, in South Africa and Thailand, called Designing and Implementing Social Protection Systems. 'The course provides participants with an in-depth understanding of the conceptual and practical issues involved in effectively designing and implementing social protection systems'. ${ }^{14}$ More than 1,000 participants from 72 countries completed this course. In 2020, EPRI launched an online version, Designing and Implementing Adaptive Social Protection Systems, to equip 'policymakers, government officials, non-governmental organisations and practitioners in navigating Covid-19 with a resilience-building response'. ${ }^{15}$

The CSP at IDS has been involved in capacity strengthening of policymakers and practitioners in governments and international agencies since its inception in 2005. The CSP has designed and delivered 2-5-day in-country training workshops to more than 300 officials from the governments of nine African countries (Botswana, Chad, Ethiopia, Lesotho, Rwanda, South Africa, Swaziland, Zambia, and Zanzibar). Some of these workshops included members of civil society and some were complemented by 'training of trainers' courses.

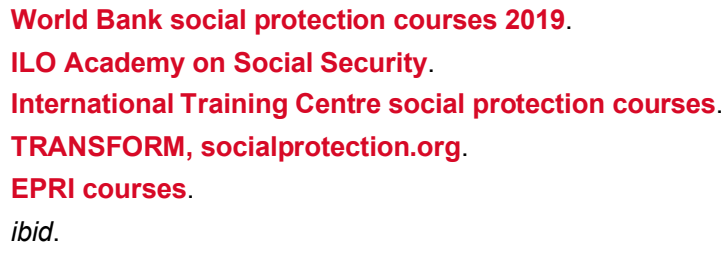


Most of these activities were sponsored by UNICEF as part of their technical support to social protection in each country.

Since social protection is still a relatively new and constantly evolving policy agenda, international development agencies also invested in building the knowledge base of their own staff. The CSP has designed 18 training courses and delivered these to over 500 staff of multilateral agencies (FAO, European Commission, UNICEF, World Food Programme (WFP)) and bilateral agencies (DFID, Irish Aid, Swiss Agency for Development and Cooperation (SDC)). Some of these courses were held at the agency headquarters, some were at IDS, and some were hosted by regional or country offices in Africa. In 2020, the CSP launched a free online course called Social Protection: A Primer with support from Irish Aid. ${ }^{16}$

Although training courses convey specific information (e.g. the difference between 'social risk management' and 'transformative social protection') and technical skills (such as how to calculate targeting errors), they also offer an unparalleled opportunity for policy pollination, by giving trainers - who are invariably employed or contracted by international agencies - a platform and a captive audience of social protection policymakers and stakeholders. Social protection is replete with design dilemmas (cash or food? conditional or unconditional? targeted or universal?) that are not technical problems but policy choices that reflect competing ideological positions. Whether consciously or unconsciously, trainers communicate their personal biases - and those of their agencies - to course participants, and this inevitably infuses policy processes when participants return home to their jobs.

\subsection{Instigating national social protection policies or strategies}

At the turn of this century not a single African country had either a National Social Protection Policy (NSPP) or a National Social Protection Strategy (NSPS). To this author's knowledge, Mali launched Africa's first NSPP in 2002, followed by Cape Verde in 2005, Senegal in 2006, Malawi in 2008, and Sierra Leone in 2009. So, by 2010 , only five out of 55 African countries had adopted a NSPP or NSPS, four of these in West Africa. Social protection as a government policy had not yet taken root in any other region, and the momentum seemed to be stalling. One observer feared that social protection might be about to collapse and become just another development policy 'bubble' that disappeared within a few years: 'in the early 2010 s there were already signs that the interest in social protection was waning' (de Haan, 2014: 315). 
However, predictions of social protection's rapid rise and imminent demise proved to be premature. In 2011 alone, five more countries published their NSPP or NSPS, doubling the total to 10. By 2019, the number had risen to 35 , almost two-thirds of the countries in Africa (64 per cent), with 30 countries publishing their social protection policy or strategy in just nine years (Figure 4.2).

\section{Figure 4.2 Cumulative National Social Protection Policies/Strategies in Africa, 2000-2019}

40

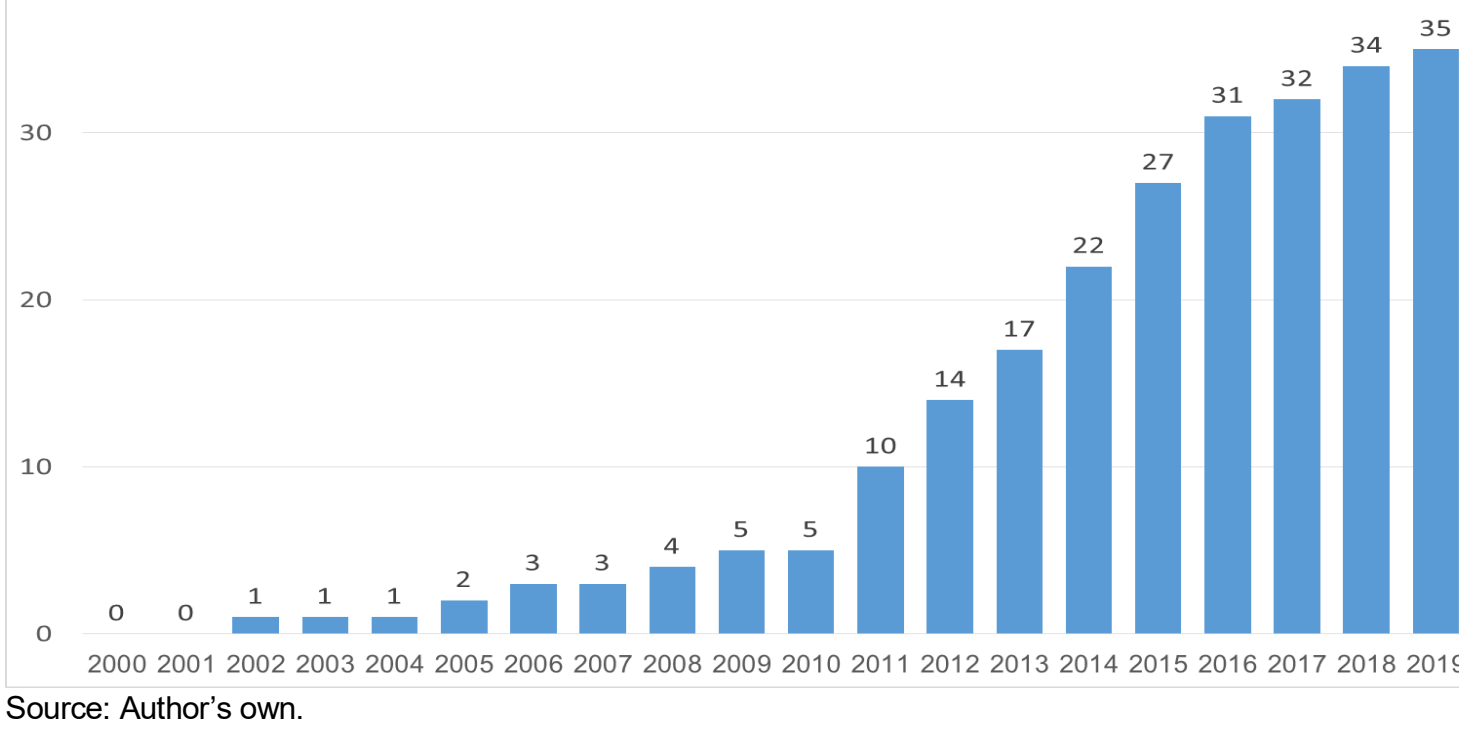

By region, West Africa dominates ( 11 out of 15 countries $=73$ per cent coverage), followed by Central Africa ( $6 / 9=67$ per cent), then East Africa (10/14 $=71$ per cent) and Southern Africa $(7 / 10=70$ per cent), with North Africa lagging behind (just 1/7 = 14 per cent) (Table 4.1).

Despite this evidence of the majority of governments across Africa promulgating social protection policies in the last decade, it does not necessarily follow that this was a nationally owned process of developing and institutionalising a domestic policy agenda in every case. For one thing, the short period in which so many countries published these documents suggests that a policy transfer process was underway, meaning that policy development in one country is influenced by the development of similar policies in other countries. 


\section{Table 4.1 National Social Protection Policies or Strategies in Africa by region, 2019}

\begin{tabular}{|l|l|l|}
\hline Region & Countries with a NSPP/NSPS & $\begin{array}{l}\text { Countries with no } \\
\text { NSPP/NSPS }\end{array}$ \\
\hline West Africa & $\begin{array}{l}\text { Burkina Faso, Cabo Verde, } \\
\text { Côte d'Ivoire, Gambia, Ghana, } \\
\text { Liberia, Mali, Niger, Nigeria, } \\
\text { Senegal, Sierra Leone }\end{array}$ & $\begin{array}{l}\text { Benin, Guinea, } \\
\text { Guinea-Bissau, Togo }\end{array}$ \\
\hline $\begin{array}{l}\text { Central } \\
\text { Africa }\end{array}$ & $\begin{array}{l}\text { Burundi, Central African } \\
\text { Republic, Chad, Democratic } \\
\text { Republic of Congo, Gabon, } \\
\text { Sao Tome and Principe }\end{array}$ & $\begin{array}{l}\text { Cameroon, Congo, Equatorial } \\
\text { Guinea }\end{array}$ \\
\hline East Africa & $\begin{array}{l}\text { Comoros, Djibouti, Ethiopia, } \\
\text { Kenya, Madagascar, Rwanda, } \\
\text { Somalia, Tanzania (mainland + } \\
\text { Zanzibar), Uganda }\end{array}$ & $\begin{array}{l}\text { Eritrea, Mauritius, Seychelles, } \\
\text { South Sudan, Sudan }\end{array}$ \\
\hline $\begin{array}{l}\text { Southern } \\
\text { Africa }\end{array}$ & $\begin{array}{l}\text { Mozambini, Lesotho, Malawi, } \\
\text { Zambia, Zimbabwe }\end{array}$ & $\begin{array}{l}\text { Angola, Botswana, } \\
\text { South Africa }\end{array}$ \\
\hline North Africa & Mauritania & $\begin{array}{l}\text { Algeria, Egypt, Libya, } \\
\text { Morocco, Western Sahara, } \\
\text { Tunisia }\end{array}$ \\
\hline
\end{tabular}

Note: This table follows the African Union regional classification.

As was the case with the wave of PRSPs that spread across the global South in the early 2000s (as discussed earlier), the wave of new social protection policies in Africa between 2002 and 2019 reflects a heavy involvement of external actors who were guiding or driving this process. Most, if not all, of these policy documents were drafted or commissioned by international agencies and their expatriate consultants, with varying degrees of involvement of national consultants and relevant government officials.

The weakly embedded nature of these donor-driven rather than nationally owned policy processes is revealed by the fact that West Africa, despite having the highest proportion of social protection policies, operates much fewer government-run social protection programmes at national scale than countries in East and Southern Africa, which have longer histories with delivering social assistance to their citizens, dating back even before the emergence of social protection as a development agency agenda in the early 2000s. South Africa introduced its first assistance programmes in the 1920s, Namibia in the 1940s and Botswana in the 1960s. All these programmes are still operating today, and many more have been introduced since, yet neither Botswana nor South Africa has a NSPP or NSPS and Namibia produced their draft Social Protection Policy 
as recently as November 2018 . One reason might be that all three are uppermiddle-income countries that already had the technical and financial capacity to design and implement these social programmes decades ago, without requiring advice or support from donor agencies and international financial institutions.

By contrast, 22 of the 35 African countries that do have a NSPP or NSPS are low-income and 12 are lower-middle-income, with high levels of involvement of international development partners in domestic policy formulation.

An interesting case of a low-income country with no NSPP despite a strong donor presence is Togo. From 2010-12, the World Bank led a process of developing a National Social Protection Policy and Strategy for Togo, which culminated in a World Bank report (the cover is reproduced below). The 'Acknowledgements' explain that the World Bank presented their draft report at a workshop that was attended by relevant government ministries and 'international partners active in social protection in Togo'. The final report 'incorporates the Government's comments' (World Bank 2012: i). However, ten years after this donor-driven process started, the Government of Togo has not yet promulgated either a National Social Protection Policy or a National Social Protection Strategy.

\section{Figure 4.3 Cover of World Bank report on a social protection policy for Togo}

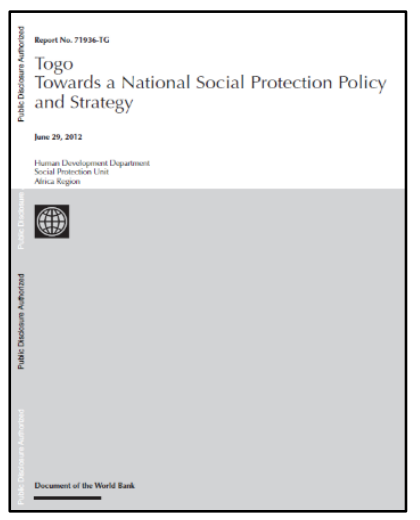

\section{'Acknowledgements}

This report was prepared by a World Bank team with support from the Government of Togo... The report draws from a series of background reports prepared by the Government and with support of various donors, including the World Bank, UNICEF, ILO, and UNDP over the last three years on different aspect of social protection in Togo. An initial draft of the report was reviewed in a national workshop in Togo in March 2012 presided by the Ministry of Work, Employment and Social Security, with attendance by the key ministries and agencies of the Government as well as international partners active in social protection in Togo. During that workshop, the ILO provided technical support to carry out an initial costing exercise. This final version incorporates the Government's comments...' (World Bank 2012: i) 
The covers of two other national social protection policy documents, from The Gambia and Liberia, display multiple symbols: the coat of arms of the country, and the institutional logos of international agencies that supported the development of the policy. In the case of The Gambia, the logos of UNDP and UNICEF are placed alongside the coat of arms. Liberia's NSPP\&S features two rows of agency logos: the European Union, Japan International Cooperation Agency (JICA), African Development Fund and World Bank above; UNICEF, World Food Programme and Concern Worldwide below (Figure 4.4). It is unclear what this signifies, but it does imply that these policies were co-produced and coowned by the national government and the international community, or even worse, that the policy positions contained in these documents reflect the ideas and objectives of the international agencies that pushed for - and paid for - their production.

\section{Figure 4.4 Covers of The Gambia and Liberia National Social Protection Policies}
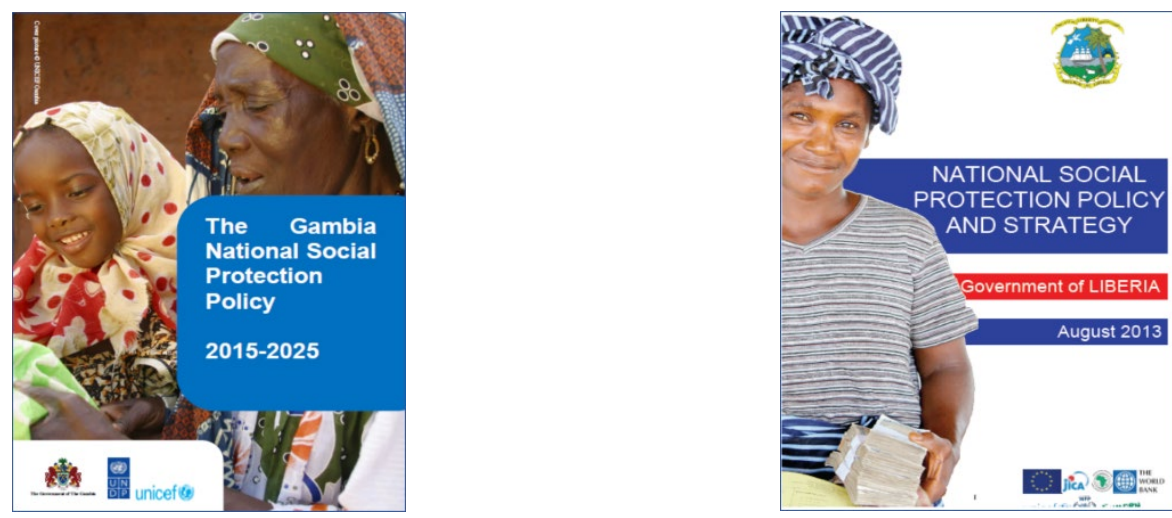

Sources: Government of The Gambia (2015) and Government of Liberia (2013)

\subsection{Domestication of international law}

A complementary explanation for the adoption of social protection by so many African governments almost simultaneously is social construction, which asserts that globalisation has been associated with a growing consensus across the world about appropriate societal goals and the appropriate actors and means to achieve them (Dobbin, Simmons and Garrett 2007). An opposite case in point is the rise since the Second World War in recognition of individual human rights (as a societal goal), the establishment of the United Nations and the International Criminal Court (as actors) and the overthrow of repressive dictatorships and their replacement with democratic institutions like regular elections and a free press (as means). 
Seen through a constructivist lens, the rapid diffusion of social protection throughout Africa could be interpreted as reflecting the voluntary incorporation of globally constructed human rights-based agendas into domestic policy processes by African governments which, after all, are active participants in the global policy forums (notably the United Nations General Assembly) where international standards are debated, resolutions are adopted and conventions are ratified. Support for this view might be found by analysing the application of international law in specific country contexts.

\section{Table 4.2 Ratification by African countries of international social protection law}

\begin{tabular}{|l|l|}
\hline $\begin{array}{l}\text { Universal Declaration of Human } \\
\text { Rights (UDHR) [1948] }\end{array}$ & $\begin{array}{l}\text { The UDHR has become customary } \\
\text { international law, so all countries are } \\
\text { bound by its main principles. }\end{array}$ \\
\hline $\begin{array}{l}\text { Social Security (Minimum Standards) } \\
\text { Convention 102 [1952] }\end{array}$ & $\begin{array}{l}\text { Only seven countries in Africa have } \\
\text { ratified Convention 102. }\end{array}$ \\
\hline $\begin{array}{l}\text { International Covenant on Economic, } \\
\text { Social and Cultural Rights (ICESCR) } \\
\text { [1966] }\end{array}$ & $\begin{array}{l}43 \text { countries in Africa have ratified } \\
\text { the ICESCR. }\end{array}$ \\
\hline $\begin{array}{l}\text { Convention on the Elimination of All } \\
\text { Forms of Discrimination against }\end{array}$ & $\begin{array}{l}\text { All African countries except two have } \\
\text { ratified CEDAW. }\end{array}$ \\
\hline $\begin{array}{l}\text { Convention on the Rights of the Child } \\
\text { (CRC) [1989] }\end{array}$ & $\begin{array}{l}\text { All African countries have ratified the } \\
\text { CRC. }\end{array}$ \\
\hline $\begin{array}{l}\text { Convention on the Rights of Persons } \\
\text { with Disabilities (CRPD) [2006] }\end{array}$ & $\begin{array}{l}39 \text { countries in Africa have ratified } \\
\text { the CRPD. }\end{array}$ \\
\hline
\end{tabular}

Source: Devereux (2017)

In 1948, the Universal Declaration of Human Rights asserted that 'everyone, as a member of society, has the right to social security' (United Nations 1948). In 1952, the ILO's Social Security (Minimum Standards) Convention 102 established the basis of modern social protection systems with nine branches of social security, ${ }^{17}$ including family benefit, health care, unemployment, and old age. In 1966, the International Covenant on Economic, Social and Cultural Rights 'recognise[d] the right of everyone to social security' (Mpedi and Nyenti 2015).

Other international conventions affirm the right to social protection or social security for specific vulnerable groups, notably the Convention on the Elimination of All Forms of Discrimination Against Women (1979), the Convention on the 
Rights of the Child (1989), and the Convention on the Rights of Persons with Disabilities (2006). Most African countries have ratified these three conventions (Table 4.2). More recently and most pertinently, in 2012 all member states of the International Labour Conference voted to adopt the Social Protection Floors Recommendation (R202), which advocates for a rights-based package that guarantees access to health care for all as well as income security for children, people of working age and older persons (ILO 2012).

The United Nations appoints Special Rapporteurs who function effectively as policy pollinators, by drafting policy statements that clarify the commitments governments have made under international law and travelling to countries to verify that member states are fulfilling their obligations. In 2012, the United Nations Special Rapporteurs on the Right to Food and on Extreme Poverty and Human Rights co-authored a proposal for a Global Fund for Social Protection (de Schutter and Sepúlveda 2012). This document helpfully clarifies the content of the right to social protection in international law and the obligations of member states to 'respect, protect, and fulfil the right to social protection' (ibid.: 5) as comprehensively and expeditiously as possible, including by passing appropriate domestic laws.

Under the International Covenant on Economic, Social and Cultural Rights (ICESCR), States must devote their maximum available resources to the fulfilment of economic and social rights, including through the establishment of social protection systems. As recognised under the ICESCR, some dimensions of economic and social rights can only be achieved progressively over time. However, this cannot be invoked as a pretext for delaying action.

(de Schutter and Sepúlveda 2012: 6)

An implicit theory of change explains how the globally affirmed human right to social protection might 'cascade' down to the realisation of this right by individuals living in specific country contexts (Devereux 2017). First, the country signs or ratifies relevant instruments in global (e.g. Union Nations) or regional (e.g. African Union) forums. Next, the provisions of these global and regional instruments are codified in national position statements such as the Constitution or National Development Plan. Third, policies, programmes and projects are designed and implemented to give effect to these provisions. Fourth, legislation is passed that gives these social protection interventions the status of a justiciable right. Finally, local civil society organisations campaign to hold the government accountable to deliver on the right to social protection.

In reality, this process plays out in very few countries. The road from ratification to implementation to enforcement is very long - in some cases, non-existent. 
For one thing, most global Declarations, Conventions, Covenants and Recommendations are not legally binding. The United Nations Special Rapporteurs have no legal authority to enforce United Nations resolutions. No government has yet been prosecuted at the International Criminal Court for violating the right to social protection. At the national level, a right to social security is specified in about half of the constitutions in Africa (14 out of 30 examined by Fombad (2011)). But in most cases, this right is not justiciable - it cannot be enforced. In South Africa, civil society has taken the government to court, to uphold or extend the right to social protection. For example, an alliance of local civil society organisations successfully lobbied Parliament and the High Court to extend the age of eligibility for the Child Support Grant from seven to 18 years, on the basis that 18 years is the legal definition of a child in South Africa (Proudlock 2009).

But South Africa is an exception to the rule, for reasons related to its unique history (Devereux 2011). In many other African countries, civil society activities are curtailed and strictly regulated, and they have no freedom to campaign for economic, social, and cultural rights. This illustrates the critical point: that national governments are accountable to their domestic constituencies and are responsive to local political imperatives, rather than to declarations signed in global forums. 


\section{Understanding resistance: why some governments say 'no'}

As seen above, evaluations of social protection programmes in Africa have found unambiguously positive impacts on a range of indicators of poverty and vulnerability. Surely governments should want to implement policies and programmes that improve the wellbeing of their poor and vulnerable citizens? But this theory of change - that policy choices are entirely evidence-based - is not necessarily aligned with political reality. Governments do have some interest in evidence of what works. But they are mostly interested in what they need to do to remain in power. From this perspective, building the evidence base is more important to donor agencies, who report on the effectiveness of their aid spending to external constituencies, not to African citizens who vote for local politicians.

Political self-interest drives government policy processes, not only in Africa but everywhere, and this is the lens through which all decisions about national social protection policies should ultimately be analysed. Governments need to be convinced that introducing a new policy and committing resources to new or scaled-up programmes will help them to win votes - in other words, policymaking is driven by 'what's popular' rather than 'what works'.

In this context, social protection is susceptible to both 'positive' and 'negative' politicisation (Devereux and White 2010). In democratic regimes with accountable governments, delivering benefits to poor people makes governments popular and earns them votes - a positive outcome for poor people and their governments. Negative politicisation occurs if governments manipulate targeting and eligibility criteria to ensure that benefits are disbursed not on the basis of need, but to their own supporters as a reward for their loyalty, or to opposition supporters to induce them to switch their vote in future elections. There are numerous examples of both forms of politicisation throughout Africa.

Lesotho's social pension became a campaigning issue in the 2007 elections, when opposition parties promised to double the amount paid to pensioners and the ruling party was forced to respond by promising to raise the payment, which they duly did after winning the election (Croome et al. 2007). This is an example of 'positive politicisation' because it was a win-win, both for pensioners and for the government. On the 'negative politicisation' side, political parties represent their constituencies rather than the nation as a whole, and disbursing benefits is often used to reinforce or expand the ruling party's political base. In Zambia, donors who argued for rolling out the SCT from poorest to less poor districts on technical criteria (based on poverty headcount rankings) faced pressure from 
politicians who wanted the SCT to be launched in their district first (irrespective of its poverty rank) (Harland 2014). In South Africa, the Child Support Grant is known by many as 'Mandela money', because it was introduced by the ANC government during Nelson Mandela's presidency, and some voters fear that if they vote for an opposition party they could lose their grants (Plagerson et al. 2012).

African governments are located at the intersection between external pressure from international development agencies to implement specific policies and programmes in certain ways - exerted through hard or soft conditions on development aid - and internal pressure from local civil society to 'do the right thing' for poor and vulnerable citizens (if such activism is tolerated by the state). The imperative driving their policy choices is not necessarily how to reduce poverty rapidly, but political survival. So perhaps social protection is spreading because politicians are acting out of enlightened self-interest.

One strategy that governments deploy to balance these competing priorities is to use the donors to finance certain programmes favoured by international agencies - such as social cash transfers - and to commit government resources to interventions that are more popular domestically. Malawi is a case in point. For over ten years the donors pushed to scale-up social cash transfers, building on a positively evaluated pilot project in Mchinji District. ${ }^{18}$ But the government preferred to allocate funds to supporting farmers with fertiliser and seed subsidies, because this is regarded as a more productive investment in a politically influential constituency. In other words, the government saw higher economic returns and more votes in giving agricultural inputs to farmers than in giving cash transfers to older persons and vulnerable children. Moreover, the government does not believe in prioritising cash transfers, which it sees as wasting scarce resources on people who don't need help (because their families and communities should support them) and who won't use the money 'productively' (because children and older persons are not working). ${ }^{19}$ Eventually the social cash transfer did scale-up to cover all districts in Malawi, but mainly through funding provided by development agencies. The World Bank, European Union, Germany, and Ireland now support the SCT programme in 27 districts, while the government finances the SCT in just one district out of 28 (Government of Malawi 2019).

The Malawi case illuminates two important asymmetries between African governments and their development partners. One is political: donor agencies believe (and have invested resources to prove) that cash transfer programmes

18 The Mchinji Social Cash Transfer Pilot Scheme was initiated and funded by UNICEF. A rigorous impact evaluation was commissioned by USAID and UNICEF, led by a researcher from Boston University. 'Evidence from Mchinji demonstrates that, in just one year, \$14 per month is capable of transforming the lives of ultra-poor households in virtually all dimensions of social and economic development' (Miller et al. 2011: 115)

19 In the late 1990s, when social pensions for older Malawians was first proposed by DFID and the World Bank, a government official dismissed the idea, rhetorically asking this author: 'Why water a dying plant?' 
uplift poor people, and that governments should therefore allocate their own resources to such spending. But governments do not necessarily regard marginalised groups among the poor as politically important constituencies. Their political interests lie elsewhere - in this case, with supporting farmers (who grow the country's food - a national strategic priority - and vote) rather than children (who do not vote) or older persons (who form a smaller part of the electorate in African countries than in OECD countries).

The second asymmetry is about the choice of instruments. For whatever reason, the international development community identified social cash transfers as their preferred instrument for addressing poverty and vulnerability in the global South in the early 2000s. This meant that they allocated funds and technical expertise towards advocating and implementing cash transfer programmes in countries where they operate - and withheld funds and technical expertise from policy instruments they do not support (such as food or fertiliser subsidies). But many African governments remain unconvinced by cash transfers, because of negative perceptions and pejorative attitudes alluded to earlier: they are too expensive for low-income countries with widespread poverty; they create dependency and underwrite laziness; poor people are irresponsible and will waste any money they are given on alcohol (men) or hairdressing (women) (Adato et al. 2016). Even if governments are persuaded by the evidence that cash transfers do have positive impacts, they are not necessarily convinced that cash transfers to children or older persons will generate higher returns (in terms of poverty reduction, food security and economic growth impacts) than fertiliser subsidies to farmers.

So when some governments seem reluctant to join in the enthusiasm of development agencies for cash transfers this is not simply stubbornness or intransigence. It reflects careful political calculations as well as genuine disagreements (which, regrettably, are rarely openly debated between African governments and their development partners) about the optimal allocation of scarce public resources in low-income settings. 


\section{Conclusion}

A particular form of social protection - social cash transfers targeted to poor and vulnerable groups - has been adopted by the majority of countries in sub-Saharan Africa during the last 20 years, backed up by financial and technical support from international agencies, the strengthening of administrative and capacities to deliver cash transfer programmes, and the drafting of national social protection policies. Several plausible explanations for this policy diffusion process have been considered in this paper, which can be framed as complementary theories of change:

- Theory of change \#1: It is an evidence-driven policy process. Social protection has been proven - through rigorous evaluations of cash transfer schemes - to achieve significant positive impacts on poverty and vulnerability. This accumulation of evidence convinced African governments to implement, scale-up and ultimately pay for their national social protection programmes.

- Theory of change \#2: It is a political choice. Politicians support policies that are electorally popular and consolidate their power. Given this context, social protection is expanding throughout Africa because delivering cash transfers is amenable to both positive and negative politicisation.

- Theory of change \#3: Social protection is well established in international law, from the Universal Declaration of Human Rights in 1948 to the Social Protection Floors Recommendation in 2012. The adoption by African governments of national social protection policies, programmes and laws simply reflects the domestication of their legal commitments under international law. ${ }^{20}$

As noted earlier, in the policy transfer literature, four causal mechanisms are commonly discussed. In three of these - learning, competition, and emulation policies are voluntarily chosen by adopting governments, while in the fourth pathway - coercion - policies are imposed on governments against their will by external actors, using their hard or soft power. This paper has focused on a pathway closely linked to coercion, that I call policy pollination.

- Theory of change \#4: Social protection has been 'pollinated' throughout Africa, especially in low-income countries, by international development agencies, using their financial leverage and technical expertise to incentivise policy adoption by aid-dependent governments. 
The extent to which this policy process was coercively imposed on reluctant African governments and the extent to which it was autonomously chosen by these governments, with support they solicited from their development partners, varies from country to country. What is clear is that powerful international development agencies invested heavily across Africa in building the evidence base that cash transfers have positive impacts, by commissioning rigorous impact evaluations of programmes they supported technically and financially. At the same time, these agencies also invested heavily in strengthening the capacity of African governments to deliver social cash transfers, and to develop policies, instruments and systems that institutionalised social protection in national policy structures.

Devereux and Kapingidza (2020: 298) propose six indicators for assessing the extent to which a social protection policy process can be characterised as 'donor-driven' rather than 'nationally owned':

1. 'Whether the policy process is conceived, designed and facilitated mainly by external actors through their advisors and consultants, or is truly led by government policymakers and officials;

2. Whether consultation processes are tokenistic and dominated by elites, or wide-ranging and genuinely inclusive of grass-roots organisations and poor people (i.e. prospective beneficiaries);

3. Whether external actors favour specific instruments (e.g. SCT) rather than other instruments that may be favoured by African governments (e.g. agricultural input subsidies);

4. If a donor-supported pilot project becomes a flagship national programme, to the detriment of existing national programmes that do not receive donor support;

5. Whether evaluations of social protection programmes are commissioned by external actors and conducted by international research institutes, or commissioned by the government and conducted by local researchers;

6. The proportion of social protection spending that is financed by external actors, versus domestic resource mobilisation and government commitment to co-financing that is actually disbursed.'

No judgement is made in this paper as to whether a donor-driven process of policy pollination is 'good' or 'bad'. Arguably, the diffusion of social protection throughout Africa, however achieved, should be seen as a 'win-win-win', since it simultaneously serves the needs of the international development community as well as national governments and, of course, the African poor. 
On the other hand, questions remain about the sustainability of social protection in those countries where external actors appear more committed to social protection than national actors. The test will come if and when development agencies withdraw their financial support and technical assistance, leaving each government to decide whether it is politically beneficial and fiscally cost-effective to continue investing in this specific set of social policy instruments. 


\section{References}

Adato, M. and Hoddinott, J. (eds) (2010) Conditional Cash Transfers in Latin America, Baltimore MA: Johns Hopkins University Press

Adato, M.; Devereux, S. and Sabates-Wheeler, R. (2016) 'Accessing the "Right" Kinds of Material and Symbolic Capital: The Role of Cash Transfers in Reducing Adolescent School Absence and Risky Behaviour in South Africa', Journal of Development Studies 52.8: 1132-1146

Adésínà, J. (2011) 'Beyond the Social Protection Paradigm: Social Policy in Africa's Development', Canadian Journal of Development Studies 32.4: 454-70

Barrientos, A. and Scott, J. (2008) Social Transfers and Growth: A Review, Manchester: Brooks World Poverty Institute

Bastagli, F. et al. (2016) Cash Transfers: What Does the Evidence Say? A Rigorous Review of Programme Impact and the Role of Design and Implementation Features, London: Overseas Development Institute

Beegle, K.; Coudouel, A. and Monsalve, E. (2018) Realizing the Full Potential of Social Safety Nets in Africa, Washington DC: World Bank

Craig, D. and Porter, D. (2003) 'Poverty Reduction Strategy Papers: A New Convergence', World Development 31.1: 53-69

Croome, D.; Nynguru, A. and Molisana, M. (2007) The Impact of the Old Age Pension on Hunger and Vulnerability: A Case Study from the Mountain Zone of Lesotho, Research Report, Maseru: Regional Hunger and Vulnerability Programme, National University of Lesotho

Davis, B. et al. (eds) (2016) From Evidence to Action: The Story of Cash Transfers and Impact Evaluation in sub-Saharan Africa, Oxford: Oxford University Press

de Haan, A. (2014) 'The Rise of Social Protection in Development: Progress, Pitfalls and Politics', European Journal of Development Research 26.3: 311-21

de Schutter, O. and Sepúlveda, M. (2012) 'Underwriting the Poor: A Global Fund for Social Protection’, Briefing Note 07, Geneva: Office of the United Nations High Commissioner for Human Rights

Devereux, S. (2017) 'The Right to Social Protection in Africa: From CCCCDFPRTs to CLSPPPs', Law in Africa 20.1: 11-32

Devereux, S. (2011) 'Social Protection in South Africa: Exceptional or Exceptionalism?', Canadian Journal of Development Studies 32.4: 414-25

Devereux, S. and Coll-Black, S. (2007) Review of Evidence and Evidence Gaps on the Effectiveness and Impacts of DFID-Supported Pilot Social Transfer Schemes, Evaluation Report A1/A3, London: DFID

Devereux, S. and Kapingidza, S. (2020) 'External Donors and Social Protection in Africa: A Case Study of Zimbabwe', in C. Schmitt (ed.), From Colonialism to International Aid: External Actors and Social Protection in the Global South, London: Palgrave

Devereux, S. and White, P. (2010) 'Social Protection in Africa: Evidence, Politics and Rights', Poverty and Public Policy 2.3: 53-77

Devereux, S.; Marshall, J.; MacAskill, J. and Pelham, L. (2005) Making Cash Count: Lessons from Cash Transfer Schemes in East and Southern Africa for Supporting the Most Vulnerable Children and Households, A Report for UNICEF, London: Save the Children UK, HelpAge International, and Brighton: Institute of Development Studies

DFID (2011) Cash Transfers Evidence Paper, London: Department for International Development

Dobbin, F.; Simmons, B. and Garrett, G. (2007) 'The Global Diffusion of Public Policies: Social Construction, Coercion, Competition, or Learning?', Annual Review of Sociology 33.1: 449-72

Dolowitz, D. and Marsh, D. (2000) 'Learning from Abroad: The Role of Policy Transfer in Contemporary Policy-Making', Governance 13: 5-24

Easterly, W. (2006) The White Man's Burden: Why the West's Efforts to Aid the Rest Have Done So Much III and So Little Good, Oxford: Oxford University Press 
Ejolu, I. (2008) 'The Poverty Reduction Strategy Paper (PRSP): A Critical Analysis of the Fundamental Limitations and a Conceptual Framework for Reform', MSc Thesis, Maastricht Graduate School of Governance, Maastricht University

Ellis, F.; Devereux, S. and White, P. (2009) Social Protection in Africa, Cheltenham: Edward Elgar Esping-Andersen, G. (1990) The Three Worlds of Welfare Capitalism, Princeton NJ: Princeton University Press

Fiszbein, A. and Schady, N. (2009) Conditional Cash Transfers: Reducing Present and Future Poverty, Washington DC: World Bank

Fombad, C. (2013) 'An Overview of the Constitutional Framework of the Right to Social Security with Special Reference to South Africa', African Journal of International and Comparative Law 21.1: 1-31

Garcia, M. and Moore, C. (2012) The Cash Dividend: The Rise of Cash Transfer Programs in sub-Saharan Africa, Washington DC: World Bank

Gough, I. and Wood, G. (2004) Insecurity and Welfare Regimes in Asia, Africa and Latin America, Cambridge: Cambridge University Press

Government of Liberia (2013) National Social Protection Policy and Strategy, Monrovia: Government of Liberia

Government of Malawi (2019) 'Social Cash Transfer Programme (SCTP) Briefing', Lilongwe: Ministry of Gender, Children, Disability and Social Welfare

Government of The Gambia (2015) The Gambia National Social Protection Policy 2015-2025, Banjul: Government of The Gambia

Handa, S.; Devereux, S. and Webb, D. (eds) (2010) Social Protection for Africa's Children, London: Routledge

Hanlon, J.; Barrientos, A. and Hulme, D. (2010) Just Give Money to the Poor: The Development Revolution from the Global South, West Hartford: Kumarian Press

Harland, C. (2014) 'Can the Expansion of Social Protection Bring About Social Transformation in African Countries? The Case of Zambia', European Journal of Development Research 26.3: 370-86

Hickey, S.; Lavers, T.; Niño-Zarazúa, M. and Seekings, J. (eds) (2019) The Politics of Social Protection in Eastern and Southern Africa, Oxford: Oxford University Press

ILO (2012) Text of the Recommendation Concerning National Floors of Social Protection, Geneva: International Labour Conference

ILO (1952) Social Security (Minimum Standards) Convention, No. 102, Geneva: International Labour Organization

IMF (2016) Poverty Reduction Strategy Papers (PRSP), Washington DC: International Monetary Fund (accessed 23 January 2020)

Leisering, L. (2019) The Global Rise of Social Cash Transfers, Oxford: Oxford University Press

Mathers, N. and Slater, R. (2014) Social Protection and Growth: Research Synthesis, Canberra: Department of Foreign Affairs and Trade (DFAT), Australian Government

MCDSS and GTZ (2007) Final Evaluation Report: Kalomo Social Cash Transfer Scheme, Lusaka: Ministry of Community Development and Social Services \& German Technical Cooperation

McKenzie, D. (2017) How Effective are Active Labor Market Policies in Developing Countries? A Critical Review of Recent Evidence, Policy Research Working Paper 8011, Washington DC: World Bank

Midgley, J. and Piachaud, D. (eds) (2011) Colonialism and Welfare: Social Policy and the British Imperial Legacy, Cheltenham: Edward Elgar

Miller, C.; Tsoka, M. and Reichert, K. (2011) 'Impacts on Children of Cash Transfers in Malawi', in S. Handa, S. Devereux and D. Webb (eds), Social Protection for Africa's Children, London: Routledge Moyo, D. (2009) Dead Aid: Why Aid is Not Working and How There Is Another Way for Africa, London: Allen Lane

Mpedi, G. and Nyenti, M. (eds) (2015) Compendium of Key International, Regional and Sub-regional Social Security Instruments, Stellenbosch: SUN Press 
Obinger, H.; Schmitt, C. and Starke, P. (2013) 'Policy Diffusion and Policy Transfer in Comparative Welfare State Research', Social Policy and Administration 47.1: 111-29

Ortiz, I.; Cummins, M. and Karunanethy, K. (2015) Fiscal Space for Social Protection: Options to Expand Social Investments in 187 Countries, Extension of Social Security (ESS) Working Paper 48, Geneva: International Labour Office

Plagerson, S.; Harpham, T. and Kielmann, K. (2012) 'Cash Transfers and Citizenship: Evidence from South Africa', Journal of Development Studies 48.7: 969-82

Polanyi, K. (1944) The Great Transformation: The Political and Economic Origins of our Time, New York NY: Beacon Press

Proudlock, P. (2009) 'Lessons Learned from the Campaigns to Extend the Child Support Grant in South Africa', in S. Handa, S. Devereux and D. Webb (eds), Social Protection for Africa's Children, London: Routledge

Robalino, D.; Rawlings, L. and Walker, I. (2012) Building Social Protection and Labor Systems: Concepts and Operational Implications, Social Protection and Labor Discussion Paper 1202, Washington DC: World Bank

Sabates-Wheeler, R.; Hurrell, A. and Devereux, S. (2015) 'Targeting Social Transfer Programmes: Comparing Design and Implementation Errors across Alternative Mechanisms', Journal of International Development 27.8: 1521-1545

Sabates-Wheeler, R.; Lind, J.; Hoddinott, J. and Tefera, M. (forthcoming) 'Graduation after 10 Years of Ethiopia's Productive Safety Net Programme: Surviving But Still Not Thriving', Development Policy Review

Samson, M. (2005) Sustainability and South Africa’s Social Security System, Cape Town: Economic Policy Research Institute

Schmitt, C. (ed.) (2020) From Colonialism to International Aid: External Actors and Social Protection in the Global South, London: Palgrave

Schmitt, C. (2015) 'Social Security Development and the Colonial Legacy', World Development 70: 332-42

Schmitt, C. and Starke, P. (2012) 'Explaining Convergence of OECD Welfare States: A Conditional Approach', Journal of European Social Policy 21.2: 120-35

Seekings, J. (2017) 'Affordability' and the Political Economy of Social Protection in Contemporary Africa, WIDER Working Paper 2017/43, Helsinki: United Nations University World Institute for Development Economics Research

Shepherd, A.; Wadugodapitiya, D. and Evans, A. (2011) 'Social Protection and the "Dependency Syndrome" ', CPRC Policy Brief 22, Manchester: Chronic Poverty Research Centre

Simms, C. (2000) Health Reformers' Response to Zambia's Childhood Mortality Crisis, IDS Working Paper 121, Brighton: Institute of Development Studies

Thome, K.; Taylor, J.E.; Filipski, M.; Davis, B. and Handa, S. (2016) The Local Economy Impacts of Social Cash Transfers: A Comparative Analysis of Seven sub-Saharan Countries, Rome: Food and Agriculture Organization

UNDP (2019) The State of Social Assistance in Africa, New York NY: United Nations Development Programme

UNICEF (2012) Social Protection Strategic Framework, New York NY: United Nations Children's Fund

United Nations (2015) Transforming Our World: The 2030 Agenda for Sustainable Development, New York NY: United Nations General Assembly

United Nations (2000) United Nations Millennium Declaration, New York NY: United Nations General Assembly

United Nations (1948) Universal Declaration of Human Rights, New York NY: United Nations General Assembly

von Gliszczynski, M. and Leisering, L. (2016) 'Constructing New Global Models of Social Security: How International Organizations Defined the Field of Social Cash Transfers in the 2000s', Journal of Social Policy 45.2: 325-43

White, P.; Hodges, A. and Greenslade, M. (2015) Measuring and Maximising Value for Money in Social Protection Systems, London: DFID 
White, P.; Hodges, A. and Greenslade, M. (2013) Guidance on Measuring and Maximising Value for Money in Social Transfer Programmes, London: DFID

Williamson, J. (2000) 'What Should the World Bank Think about the Washington Consensus?', World Bank Research Observer 15.2: 251-64

World Bank (2018) The State of Social Safety Nets 2018, Washington DC: World Bank

World Bank (2012) Togo: Towards a National Social Protection Policy and Strategy, Washington DC: World Bank

World Bank (2001) Social Protection Sector Strategy: From Safety Net to Springboard, Washington DC: World Bank

World Bank (1990) World Development Report 1990: Poverty, Washington DC: World Bank 


\section{(2) institute of development \\ studies}

Delivering world-class research, learning and teaching that transforms the knowledge, action and leadership needed for more equitable and sustainable development globally.

Institute of Development Studies

Library Road

Brighton, BN1 9RE

United Kingdom

+44 (0)1273606261

ids.ac.uk

Charity Registration Number 306371

Charitable Company Number 877338

(C) Institute of Development Studies 2020 